\title{
Tidal and wind-event variability and the distribution of two groups of Pseudo-nitzschia species in an upwelling-influenced ría
}

\author{
Patricio A. Díaz ${ }^{a, *}$, Manuel Ruiz-Villarreal ${ }^{b}$, Lourdes Velo-Suárez ${ }^{a, c}$, Isabel Ramilo ${ }^{a}$, Patrick Gentien $^{c}$, \\ Michel Lunven ${ }^{c}$, Liam Fernand $^{d}$, Robin Raine ${ }^{\mathrm{e}}$, Beatriz Reguera ${ }^{\mathrm{a}}$ \\ a Instituto Español de Oceanografía (IEO), Centro Oceanográfico de Vigo, Subida a Radio Faro 50, 36390 Vigo, \\ Spain \\ ${ }^{b}$ IEO, Centro Oceanográfico de A Coruña, Muelle de las Ánimas s/n, 15001, A Coruña, Spain \\ ${ }^{c}$ Institut Français de Recherche pour l'Exploitation de la Mer (IFREMER), Centre de Brest, Pointe du Diable BP \\ 70, 29280 Plouzané, France \\ d Centre for Environment Fisheries and Aquaculture Science (CEFAS), Pakefield Road, Lowestoft, Suffolk, NR33 \\ OHT, United Kingdom \\ e The Ryan Institute, National University of Ireland, Galway, University Road, Galway, Ireland
}

*: Corresponding author : Patricio A. Diaz, tel. +34-986-492111; fax. +34-986-498626 ; email address : patricio.diaz@vi.ieo.es

\begin{abstract}
:
High-resolution physical and biological measurements were carried out in May-June 2007 during the „HABIT-Pontevedra 2007' survey in Ría de Pontevedra (Galician Rías Baixas, NW Spain) to study small-scale physical-biological interactions in the distribution of microphytoplankton, with special emphasis on harmful species. Longitudinal transects from the Ría to the adjacent shelf were sampled to describe the spring-neap tidal and circadian variability. An in situ particle profiler, a moored ADCP, and a towed undulating CTD (Scanfish) were used during the survey, which took place after an upwelling pulse at neap tides during a downwelling-upwelling cycle and coincided with the annual maximum of Pseudo-nitzschia spp. Cell maxima of $P$. seriata $\left(2 \times 10^{6}\right.$ cells $\left.L^{-1}\right)$ and $P$. delicatissima $\left(6 \times 10^{5}\right.$ cells $\left.\mathrm{L}^{-1}\right)$ groups were observed during the first half of the cruise during downwelling, and $a$ significant decrease in cell numbers occurred during subsequent relaxation-upwelling conditions. Thin layers were eroded during downwelling and formed again in the subsequent upwelling pulse. Cells of the $P$. seriata group were always dominant in terms of biomass but the contribution of the $P$. delicatissima group increased with stratification. Water exchange between the Ría and the adjacent shelf was mainly controlled by the upwelling/downwelling cycle, and tidal (both semidiurnal and springneap) variability appeared as a modulation of the response of the Ría circulation to wind variability. The circadian variability was regulated by tidal forcing, and Pseudo-nitzschia spp. maxima were associated with high stratification during low tide. The magnitude of spring-neap tidal and circadian variability has to be considered when designing and implementing water quality and harmful algae monitoring programmes. Blooms of Pseudo-nitzschia ssp. were not associated with the occurrence of domoic acid in shellfish even when Pseudo-nitzschia australis was dominant. These results confirm that just cell densities of the potential toxin producer are not enough for early warning in monitoring of Pseudo-nitzschia events..
\end{abstract}


Keywords : Pseudo-nitzschia spp. ; Upwelling-downwelling cycle ; Spring-neap tidal variability ; Thin layers ; Circadian variability ; Galician Rías

\section{Introduction}

Pseudo-nitzschia H. Peragallo is a cosmopolitan diatom genus comprising about 37 species that are regular bloom-producers (Fryxell and Hasle, 2002; Trainer et al., 2012). Twelve species of this genus may produce domoic acid (DA) (Lundholm, 2012), a neurotoxin which causes Amnesic Shellfish Poisoning (ASP) in humans (Bates et al., 1989), birds (Sierra-Beltrán et al., 1997; Work et al., 1993) and marine mammals (Scholin et al., 2000). Eight potentially toxic species of Pseudo-nitzschia have been reported in the Galician Rías (NW Iberian Peninsula) (Table 1), but short-lasting ASP outbreaks in this area have been mainly associated with high concentrations (> 105 cell $\mathrm{l}-1$ ) of $P$. australis (Fraga et al., 1998; Míguez et al., 1996). Wind forcing has been identified as the main factor controlling Harmful Algal Blooms (HABs) in upwelling systems (GEOHAB, 2005), but detailed information on the conditions affecting the occurrence of each HAB species is needed (Pitcher, 2012). Studies in the California and the Benguela Current Systems have shown that populations of Pseudo-nitzschia species developed in offshore retention areas ("incubators") may be advected to the coast during periods of downwelling-favourable winds on time scales of a few days, because surface currents respond quickly to shifts in local wind forcing (Adams et al., 2006; Fawcett et al., 2007; Trainer et al., 2000; Trainer et al., 2002). Further, intensive subsurface chlorophyll maxima (SCM) and thin 
layers dominated by Pseudo-nitzschia spp. have been described off Oregon in the California Current System (McManus et al., 2003; Rines et al., 2002; Trainer et al., 2002).

In the Galician Rías, on the northern limit of the Canary Current System (Fig. 1), the annual phytoplankton succession shows a clear temperate-seas seasonal pattern superimposed by the short term (1-2 weeks) and annual variability of the upwelling regime (Margalef et al., 1955; Nogueira and Figueiras, 2005; Nogueira et al., 1997). Toxic harmful algae events in this region occur during the upwelling season and peak in the transition to winter conditions (Escalera et al., 2010; Reguera et al., 2008; Trainer et al., 2010). Blooms of Pseudo-nitzschia spp. in late spring and summer have been reported in the Galician Rías Baixas associated with variations in watercolumn stratification and nutrient availability induced by upwelling and its relaxation (Figueiras and Ríos, 1993; Rodríguez et al., 2003; Varela et al., 2004, 2008; Velo-Suárez et al., 2008). These studies reported Pseudo-nitzschia spp. in the SCM co-occurring with other diatoms, usually Chaetoceros spp. Hydrodynamic and meteorological factors, such as currents and wind, have been suggested as key factors to explain short-term spatial and temporal distribution patterns in Pseudo-nitzschia spp. (Velo-Suárez et al., 2010; Velo-Suárez et al., 2008), and the interannual variability of ASP outbreaks (Álvarez-Salgado et al., 2011). Velo-Suárez et al. (2008) observed that the distribution of Pseudo-nitzschia spp. is closely related to the upwellingdownwelling cycles, because steep pycnoclines established after upwelling pulses may act as retention areas for these populations, leading to formation of diatom thin layers (up to $30 \mu \mathrm{g}$ chl$a$ equiv $\left.1^{-1}\right)$.

The short-term variability in upwelling systems in temperate latitudes is mainly due to the fact that $70 \%$ of the wind regime variability there is concentrated in periods of less than 30 days, with a typical scale for these events of 3-14 days (Álvarez-Salgado et al., 2003; Blanton et al., 
1984; Nogueira et al., 1997; Torres et al., 2003). Thus, changes in the wind directions cause a succession of upwelling and downwelling events that generate complex circulation patterns. These patterns affect phytoplankton distribution and may induce transport of offshore plankton communities into coastal embayments (Escalera et al., 2010; Pitcher et al., 2010; Roegner et al., 2002; Trainer et al., 2010). Trainer et al. (2002) presented a conceptual model in which the anticyclonic Juan de Fuca eddy acts as a retention area (“incubator") for Pseudo-nitzschia populations, which under favourable wind shifts can be transported onshore resulting in quick contamination with DA of coastal razor clam (Siliqua patula) beds.

Short-term variability of phytoplankton induced by high-frequency physical and biological processes may at certain times and places be more important than that associated with longer time scale processes. In shallow coastal waters, for example, tides constitute one of the main sources of short-term variability leading to changes in phytoplankton distribution at time scales of hours (Cloern et al., 1989).

Intensive shellfish production occurs in the Galician Rías - $300 \times 10^{3} \mathrm{t}^{-1}$ of blue mussels and $17 \times 10^{3} \mathrm{t}$ of other shellfish species - per year (FAO, 2012). Toxin-producing microalgae in general, and DA producing Pseudo-nitzschia spp. in particular, represent a serious threat to sustainable exploitation of shellfish resources in the region. The impact of Pseudo-nitzschia spp. is specially hard on scallops (Pecten maximus, P. jacobeus), which have a slow depuration rate for DA and related compounds, and once they take up these toxins may keep them above regulatory levels all year round (Salgado et al., 2003). Nevertheless, a detailed understanding of the physical and biological processes involved in the temporal and spatial dynamics of these harmful diatom species (particularly on short-time scales) is scarce. Consideration of changes in cell density on time scales of a few hours (semidiurnal tide-scale) is frequently missing in 
sampling strategies. In this context, a good understanding of this short-term variability is a key aspect for the development of operational models and improved risk assessment of shellfish poisoning and other hazardous events in the region. This paper evaluates the effect of springneap tidal and circadian variability and its coupling to meteorological events on the distribution of microphytoplankton using high-resolution instruments, with a special emphasis on two groups of diatoms of the genus Pseudo-nitzschia (P. seriata and P. delicatissima groups) during a downwelling-upwelling sequence.

\section{Material and methods}

\subsection{Study area}

The Galician Rías Baixas region is under the influence of the North Atlantic weather system, with an oceanic climate tending to aridity in summer (Wooster et al., 1976). The meteorological dynamics is highly conditioned by the seasonal evolution of two atmospheric systems, the Azores high and the Iceland low, where the annual variability is generated by the displacement of atmospheric high-low pressures, favouring upwelling or downwelling events (Varela et al., 2005; Wooster et al., 1976). In the Rías Baixas, northerly upwelling-promoting winds (from now on referred as "northerlies") predominate from April to October; southerly downwellingpromoting winds (from now on referred as "southerlies") predominate the rest of the year and the beginning of the upwelling and downwelling "seasons" are preceded by a spring and autumn transition period respectively (Figueiras et al., 2002; McClain et al., 1986).

Ría de Pontevedra is the second largest of the Galician Rías Baixas $\left(141 \mathrm{~km}^{2}\right.$ surface and 3.45

$\mathrm{km}^{3}$ volume), a group of four drowned river valleys in Northwest Spain (Fig. 1). This V-shaped ría, with a SW-NE direction, has a mean depth of $31 \mathrm{~m}$, and widens progressively from the 
Tambo islet toward the mouth. Two islands (Ons and Onza) act as protective barriers against the swell of the open sea and delimit two entrances to the mouth of the Ría. The northern entrance has a width of $3.7 \mathrm{~km}$ and a mean depth of $14 \mathrm{~m}$. The southern entrance is wider $(7 \mathrm{~km})$ and deeper $(60 \mathrm{~m})$ and constitutes the main water-exchange channel between the Ría and its adjacent shelf.

The outflow of the 57-km long Lérez River is at the innermost part of Ría de Pontevedra. The monthly discharge rate of this river fluctuates between 2 and $80 \mathrm{~m}^{3} \mathrm{~s}^{-1}$, with a mean of $25.9 \mathrm{~m}^{3} \mathrm{~s}^{-}$ ${ }^{1}$, following a similar pattern to that of the rainfall (de Castro et al., 2000; Prego et al., 2001). Semidiurnal tides in the Ría de Pontevedra have amplitudes range from $2 \mathrm{~m}$ (neap tides) to $4 \mathrm{~m}$ (spring tides). The tidal prism is much larger than the volume of the river flow into the Ría, causing tides to overwhelm the latter in the estuarine circulation (Ruiz-Villarreal et al., 2002). Average tidal velocities range from 0.05 to $0.1 \mathrm{~m} \mathrm{~s}^{-1}$, with maximum velocities observed of around $0.3 \mathrm{~m} \mathrm{~s}^{-1}$. Wind forcing can induce higher velocities (up to $1 \mathrm{~m} \mathrm{~s}^{-1}$ ) in surface layers, and a transverse (across-channel) component of the circulation, which may play an important role in hydrodynamic processes inside the Ría, has been described by Ruiz-Villarreal et al (2002).

\subsection{Field sampling}

The study was carried out on board R/V Mytilus from 28 May to 7 June 2007. Measurements of physical properties of the water column were carried out with advanced high resolution instruments described below. Six stations were sampled during the cruise (Fig. 1, Table 2). Of these, stations 1 to 4 (full stations), aligned along the axis of the Ría, were sampled several times during the whole cruise. Water samples were collected for nutrient, toxins and quantitative analyses of microphytoplankton to describe the spring-neap and circadian tidal variability of 
nano and microplanktonic populations. Special attention was focused on potentially harmful microalgae that are frequent at this time of the year (Pseudo-nitzschia spp. and Dinophysis spp.). Current velocities were measured continuously with a bottom-mounted ADCP (Nortek $600 \mathrm{kHz}$ Aquadopp, bin size: $1 \mathrm{~m}, 10$-min frequency) at a depth of $45 \mathrm{~m}$ (st. 3) in the navigation channel (Fig. 1).

The IFREMER - Scanfish PS19 was towed along a longitudinal transect from the middle reaches of the Ría to the adjacent shelf (Fig. 1B; Table 2). This instrument was developed for high-speed oceanographic data acquisition and designed to undulate at depths from 1 to $60 \mathrm{~m}$ and speeds of 1 to 8 knots. The system provides quasi real-time 2-D pictures of the hydrographic structure of the water column. A CTD SBE 19+ probe (Sea-Bird Electronics, Washington, USA) was integrated inside the hydrodynamic structure of the Scanfish, allowing simultaneous measurement of depth, temperature, salinity and fluorescence with a Seapoint fluorometer (Seapoint sensors, Exeter, USA) and of turbidity with a Wetlabs backscatter sensor (Wetlabs, Philomath, USA).

The IFREMER particle size analysis profiler (PSA) was used to obtain vertical profiles of temperature, salinity, chlorophyll-like fluorescence, optical back-scattering and photosynthetically active radiation (PAR) at all stations during the cruise. The PSA-system is a profiling instrument that allows high-resolution descriptions of the hydrography and the particle characteristics of the water column. It can distinguish between multiple layers even within a steep thermocline. This system is composed of an SBE 25 CTD Probe (Sea-Bird Electronics, Washington, USA), a fluorescence sensor (Seapoint Sensors, Inc., Exeter, New Hampshire, USA), and a particle size analyser (CILAS, Orléans, France). Based on diffraction pattern analysis, the PSA measures the total volume of particles in an 8-mL free flow cell and their size 
distribution over 30 classes from 0.7 to $400 \mathrm{~mm}$ (Gentien et al., 1995). The diffraction method enables quantification of different particle populations: sedimentary particles, phytoplankton, and aggregates (Lunven et al., 2005).

A previous quantitative estimate of in situ chlorophyll a (chl- $a$ ) was performed by computing the relationship between in situ fluorescence and laboratory chl- $a(\mu \mathrm{g} \mathrm{L}-1)$ values. This calibration was applied to all the fluorometer data. At each station, the PSAsystem was lowered at a speed of $0.3 \mathrm{~m} \mathrm{~s}^{-1}$, allowing an accurate assessment of the hydrological characteristics of the water column and the detection of water layers with distinct characteristics. During the up-cast, finer-scale measurements were carried out within these layers, and the instrument was stopped to collect samples from depths where structures of interest (fluorescence and particle-load maxima, pycnocline, and other density discontinuities) were detected. A 40-mm-diameter hose attached to the profiler, close to the sensors, allowed an accurate sampling of specific layers. The tubing of the seawater circuit was composed of inert non biodegradable materials to avoid contamination of the nutrient samples. The use of a peristaltic pump, with a flow rate of 30 $\mathrm{L} \min ^{-1}$, through a wide-bore pipe ensured minimum damage to delicate organisms. Microscopic observations onboard have shown that this sampling method, which allows collection of living cells from their precise in situ locations, does not injure cellular structures.

Weekly samples for phytoplankton counts in the Galician monitoring programme (INTECMAR) are collected with a dividable $(0-5,5-10,10-15 \mathrm{~m})$ hose sampler (Lindahl, 1986) at 10 stations in Ría de Pontevedra (Fig. 1C), and immediately fixed with acidic Lugol's solution (Lovegrove, 1960). 
During the cruise all samples were collected using the PSA-pump system. In addition, plankton net hauls and pump concentrates were used for immediate qualitative analyses to detect target and dominant species of the microphytoplankton community.

The circadian variability of Pseudo-nitzschia spp. and accompanying microphytoplankton species was evaluated through two intensive 24-h samplings carried out at station 2 (Fig. 1C).

The first 24-h cycle study was performed from 1930h on May 29 to 2000h on 30 May and the second, from $1000 \mathrm{~h}$ on 6 June to $1000 \mathrm{~h}$ on 7 June. Vertical CTD profiles were obtained with the PSA-system every 2-h during the two cycles.

For quantitative analyses of microphytoplankton, two kinds of samples were collected from discrete depths with the peristaltic pump: (1) unconcentrated seawater samples, to analyze the whole microphytoplankton community, and (2) 1-liter seawater samples, concentrated through $20-\mu \mathrm{m}$ nytex filters and resuspended into $50 \mathrm{~mL}$ of filtered seawater, to enumerate large and scarce species (i.e., Dinophysis spp.). Both kinds of samples were immediately fixed with Lugol's iodine acidic solution.

\subsection{Meteorology and hydrological data processing}

Wind speed and direction data were obtained from a buoy (Seawatch, Oceanor) of the national port system (Puertos del Estado) network deployed at Cabo Silleiro $\left(42^{\circ} 7.89 \mathrm{~N}-9^{\circ} 23.49 \mathrm{~W}\right)$

(Fig. 1B); upwelling indices every $6 \mathrm{~h}$, obtained from the Spanish Institute of Oceanography (www.indicedeafloramiento.ieo.es), were estimated according to Bakun (1973) using geostrophic wind data off Cape Silleiro, a representative station for the study area. Monthly averages of rainfall data between 1961 and 2007 from a meteorological station at Vigo airport 
(Peinador) $\left(42^{\circ} 13.89^{`} \mathrm{~N}, 8^{\circ} 37.29^{`} \mathrm{~W}\right)$ were provided by the Spanish Meteorological Agency (www.aemet.es).

Tides and sea level measurements were taken from a tidal gauge, from the IEO Network, at the Ría de Vigo harbour, to the south of Pontevedra (http://indamar.ieo.es/). Differences in the amplitude $(<10 \mathrm{~cm})$ and tidal phase $(1-2 \mathrm{~min})$ in the tides semidiurnal component in both rías are negligible.

Reported currents are based on raw ADCP data using the Nortek manufacturer software (Surge), and later visualized and analyzed using Matlab® (The MathWorks Inc.). Wind and ADCP data were treated with a low-pass Lanczos filter at half power of $30 \mathrm{~h}$ to eliminate tidal frequencies and estimate residual transport (subtidal variation).

Data obtained with the CTD probe SBE25 was processed using the Seasoft software provided by the manufacturer. Vertical profiles of temperature, salinity and sigma-t were plotted using Grapher 8.0 (Golden Software Inc.).

\subsection{Nutrients}

Seawater samples for inorganic nutrients $\left(\mathrm{NO}_{3}-\mathrm{NO}_{2}^{-}, \mathrm{NH}_{4}{ }^{+}, \mathrm{PO}_{4}{ }^{-}\right)$from stations 2 and 3 were taken with the PSA system from stations 2 and 3 . These were filtered through Gelman $10-\mu \mathrm{m}$ polypropylene membrane filters and frozen $\left(-25^{\circ} \mathrm{C}\right)$ immediately. For silicate determination, the water was filtered through $0.8-\mu \mathrm{m}$ cellulose nitrate membrane filters using an all-plastic device, and preserved by adding mercuric chloride (20 $\left.\mathrm{mg} \mathrm{L}^{-1}\right)$. Analyses were performed in the laboratory using a Technicon Autoanalyzer according to the methods described in Aminot and Kerouel (2007). 


\subsection{Microphytoplankton analyses}

Quantitative analyses of microphytoplankton in the unconcentrated lugol-fixed seawater samples was carried out according to Utermöhl (1958). Samples of $25 \mathrm{~mL}$ were left to settle for 24h. The detection level using this method was 40 cells $\mathrm{L}^{-1}$ (i.e., 1 cell detected after examination of the entire surface of the sedimentation chamber base-plate). Microphytoplankton abundance was determined to species level when possible. Pseudo-nitzschia species were separated into two groups, $P$. delicatissima- and $P$. seriata-group, on the basis of their valve width (Hasle, 1965). Large scarce species were counted after scanning the whole area of the sedimentation chamber at 100X magnification under an inverted microscope (Nikon Eclipse 2000). Two transects at 400X magnification were scanned to enumerate the smaller and more abundant species. To increase the detection level of scarce harmful species (i.e. Dinophysis spp.), 10-mL aliquots of the concentrated samples (factor: 1: 20) were placed in sedimentation chambers, and the whole surface of the chamber scanned at a magnification of 100X, so that the detection limit was 5 cell $\mathrm{L}^{-1}$.

Identification of Pseudo-nitzschia species by its morphological features with conventional microscopic methods is unfeasible. To describe the valve morphology of Pseudo-nitzschia cells of the $P$. seriata group, Lugol-fixed samples were treated with a solution of $\mathrm{HNO}_{3}$ and $\mathrm{H}_{2} \mathrm{SO}_{4}$ (1:4 ratio) to remove the organic material, heated using an alcohol lamp, and rinsed five times with distilled water following cooling for several minutes. A drop of the processed sample was mounted on Naphrax (Northern Supplies Limited, Ipswich, UK) and examined and photographed under a phase contrast microscope (LEICA DMLA, Wetzlar, Germany). Species were identified following Hasle (1965) and Hasle \& Syvertsen (1996), considering length and width of the cells, presence/absence of a central nodule, density of interstriae and the 
overlapping of consecutive cells in the colonies. This protocol can not be used for the accurate identification of Pseudo-nitzschia species of the P. delicatissima group, which requires observations under scanning electron microscopy.

Phytoplankton distribution can be very patchy on short time scales. To smooth variability associated with tidal changes and local wind forcing, the arithmetic mean of the weekly concentrations of all (10) monitoring stations (integrated 0-15 m hose samples) within the Ría were used to show the annual variability of Pseudo-nitzschia spp.

\subsection{Toxins analyses}

Samples with a density of Pseudo-nitzschia spp. above $5 \times 10^{5}$ cells $\cdot \mathrm{L}^{-1}$ were selected for toxin analysis. This represented a total of some 20 samples. For concentration of particulate DA in water samples, 1-2 $\mathrm{L}$ of seawater was filtered onto a $47 \mathrm{~mm}$ Whatman $\mathrm{GF} / \mathrm{C}$ glass fibre filter. The filter was kept frozen in 50\% aqueous methanol solution until analysis. The samples were sonicated for $3 \mathrm{~min}$ with a probe (100W) and centrifuged at $5000 \mathrm{rpm}$ for $10 \mathrm{~min}$. The supernatant was filtered (nylon filter, $11 \mathrm{~mm}$ diameter, $0.22 \mu \mathrm{m}$ pore size) and analyzed by liquid chromatography-multiple tandem mass spectrometry (LC-MS) using a quadrupole iontrap mass spectrometer (LCQ, ThermoFinnigan, San Jose, CA, USA) according to Furey et al. (2001). The detection limit with this method is $0.02 \mu \mathrm{g} \mathrm{DA} \mathrm{mL} L^{-1}$.

Analyses of ASP toxins (DA and its isomers) in shellfish were carried out by the Galician Monitoring Centre using an HPLC-UV reference method based on Quilliam et al. (1989). The detection limit with this method is approximately $0.5 \mathrm{mg} \mathrm{DA} \mathrm{kg}^{-1}$, well below the EU regulatory limit of $20 \mathrm{mg} \mathrm{DA} \mathrm{kg}^{-1}$. 


\subsection{Satellite images}

Moderate Resolution Imaging Spectroradiometer (MODIS) and Medium Resolution Imaging Spectrometer (MERIS) derived images were used to observe horizontal distribution of sea surface temperature (SST) and to estimate Chl- $a$ concentration using standard global algorithms (e.g. OC3 algorithm for MODIS images and Algal 1 algorithm for MERIS images) (Doerffer and Schiller, 2007; Moore et al., 2009). MODIS and MERIS data are usually captured at $1 \mathrm{~km}$. Nevertheless, MODIS $500 \mathrm{~m}$ spatial resolution ocean colour data reprocessed by NEODAAS, following the methodology presented in Shutler et al. (2007), was used here to increase resolution within the Rías. The day pass of the MODIS satellite over the study area provides simultaneous values of Chl- $a$ and SST. Pixels in MODIS SST images with MODIS L2 flags SSTWARN and SSTFAIL have been masked.

\subsection{Statistical analysis}

Principal component analysis (PCA) was used to evaluate the structure of the microphytoplankton community during the survey and its relationship with environmental variables (temperature, salinity, sigma-t and fluorescence). The analysis was carried out with 191 samples and 44 taxa that were present in at least $20 \%$ of the samples. This reduction was used to eliminate double zero values, which can distort the analysis results. Abundances were transformed to $\log [\mathrm{x}+1]$ to reduce and homogenize the variance. The PCA was performed using the statistical and programming software R 2.1.12 (R Development Core Team, 2012), package "vegan", available through the CRAN repository (www.r-project.org).

\section{Results}




\subsection{Meteorological and hydrographical conditions}

Total rainfall during 2007 was $1038 \mathrm{~mm}$, almost half of the historic annual mean $(1885 \mathrm{~mm})$ of 47 years (1961-2007). In the winter-spring months preceding the survey (January-May), the negative anomaly was even higher (60\% below the historic mean).

The tidal cycle showed a clear-cut semidiurnal signal. The maximum tidal range during the cruise was $4 \mathrm{~m}$ during spring tides on 4 June (Fig. 2A). Northerlies generating offshore Ekman transport, with a maximum estimate of $2280 \mathrm{~m}^{3} \mathrm{~s}^{-1} \mathrm{~km}^{-1}$ on 20 May, prevailed in the two weeks preceding the survey (12 to 27 May 2007) (Figs. 2B and C) and were still observed (maximum velocity of $6.8 \mathrm{~m} \mathrm{~s}^{-1}$ ) at the beginning of the survey on 28 May. From 29 May to 2 June there was a wind shift and southerlies (up to $7.3 \mathrm{~m} \mathrm{~s}^{-1}$ ) became predominant resulting in onshore Ekman transport with a maximum estimate of $620 \mathrm{~m}^{3} \mathrm{~s}^{-1} \mathrm{~km}^{-1}$. During the second half of the cruise, there was a new shift to strong northerlies $\left(11.3 \mathrm{~m} \mathrm{~s}^{-1}\right)$ with a maximum of $1535 \mathrm{~m}^{3} \mathrm{~s}^{-1}$ $\mathrm{km}^{-1}$ offshore Ekman transport on 6 June (Figs. 2B and C). Lower winds of both components were observed towards the end of the cruise (6-7 June) leading to upwelling relaxation (Fig. 2B).

Surface temperature ranged from 14.8 to $16.8^{\circ} \mathrm{C}$ at station 2 . A well-mixed water column at the beginning of the survey gave way to a well stratified structure during the second half, with a maximum gradient of $2.9^{\circ} \mathrm{C} / 10 \mathrm{~m}$ on $6 \mathrm{June}$ (Fig. 2D). Surface salinity ranged from 35.2 to 35.5 (Fig. 2E). Changes in the thermohaline structure at station 2 indicated the upwelling of colder Eastern North Atlantic Central Water (ENACW), evidenced by the elevation of the isolines from the shelf to the ría (Fraga, 1981) by the end of the survey (6 June) (Figs. 2D and E). The distribution of chl- $a$ fluorescence on 29 May revealed a SCM between 18 and $22 \mathrm{~m}$ which had a peak intensity of $9.7 \mu \mathrm{g}$ chl- $a$ equiv. $\mathrm{L}^{-1}$. A second narrow SCM was observed between 12 and 
$17 \mathrm{~m}$ with a peak intensity of $7.1 \mu \mathrm{g}$ chl- $a$ equiv. $\mathrm{L}^{-1}$ on $6 \mathrm{June}$ (Fig. $\left.2 \mathrm{~F}\right)$. In the surface layer (0$5 \mathrm{~m}$ depth), chl- $a$ fluorescence values did not exceed $1 \mu \mathrm{g}$ chl- $a$ equiv. $\mathrm{L}^{-1}$.

The instantaneous flow variability within the Ría de Pontevedra was dominated by a semidiurnal tidal signal, with inflow and outflow pulses taking place in periods of about $12 \mathrm{~h}$ (Fig 3A). The east-west component of the flow predominated with velocities 2-3 fold higher than the northsouth component (Figs. 3B and C). Maximum flow velocities $\left(0.2 \mathrm{~m} \mathrm{~s}^{-1}\right)$ were observed from 4 to 5 June associated with the upwelling pulse and maximum ( $2.5 \mathrm{~m}$ ) tidal amplitude (Fig. 3B). The low-pass filtered fluctuations of shelf winds and current velocity during the survey showed two distinct phases: the first dominated by southerly and the second by strong northerly winds (Fig. 4A). A two-layered circulation pattern, already described for the Galician Rías Baixas (Chase, 1975; de Castro et al., 2000) was observed during the cruise: inflow in the surface layer ( $<20 \mathrm{~m}$ depth) and outflow in the bottom layer when southerlies were predominant (reverse circulation), and the opposite (positive circulation) after wind reversal (Fig. 4B) when colder mixed waters reached the $10 \mathrm{~m}$ isobath (Fig. 2).

Inorganic (dissolved inorganic nitrogen -DIN-, phosphates and silicates) nutrient concentrations were extremely low in the surface layer and showed maximum values—silicates $\left(6.6 \mu \mathrm{mol} \mathrm{L}^{-1}\right)$, phosphates $\left(0.86 \mu \mathrm{mol} \mathrm{L}^{-1}\right)$ and DIN $\left(12.1 \mu \mathrm{mol} \mathrm{L}^{-1}\right)$-below $20 \mathrm{~m}$ from 4 to 6 June associated with the upwelling of nutrient-rich ENACW. On 30 May nutrient concentrations, especially silicates, were much lower in the chl- $a$ maximum (21-23 m) and practically depleted in surface waters at station 2 (Fig. 5A). A shallower intensified SCM was observed on 6 June at station 2 associated with nutrients injection in sub-surface layers and establishment of the thermocline (Fig. 5B). 
The thermohaline structure was illustrated through two Scanfish transects (longitudinal axis perpendicular to the coastline) run from the middle reaches of Ría de Pontevedra to the adjacent shelf (Figs. 6A and B). SST ranged from 14.2 to $15.4^{\circ} \mathrm{C}$ in the first transect on $1 \mathrm{June}$ and from 14.8 to $17.2^{\circ} \mathrm{C}$ in the second on 4 June (Figs. $6 \mathrm{C}$ and D). ENACW was detected at $40 \mathrm{~m}$ depth on 4 June by the adjacent shelf and at $20 \mathrm{~m}$ depth within the Ría during the second transect sampling (Figs. 6D and F). Maximum stratification inside the Ría appeared associated with a maximum density gradient $\left(0.7 \sigma_{\mathrm{t}}\right.$ between 1 and $5 \mathrm{~m}$ depth) in the second transect (4 June) performed after the upwelling pulse (Fig. 6H). The distribution of chl- $a$ fluorescence along the two transects showed maximum concentrations on the adjacent shelf with peak intensity of 7.9 $\mu \mathrm{g}$ chl- $a$ equiv. $\mathrm{L}^{-1}$ at $43 \mathrm{~m}$ depth and $7.2 \mu \mathrm{g}$ chl- $a$ equiv. $\mathrm{L}^{-1}$ at $23 \mathrm{~m}$ during the first and second transects, respectively (Figs. 6I and J).

\subsection{Distribution of microphytoplankton and Pseudo-nitzschia spp.}

The survey coincided with the annual maximum of Pseudo-nitzschia spp. in the Galician Rías Baixas. Weekly monitoring (INTECMAR) results showed a maximum concentration around $1.2 \times 10^{6}$ cells L ${ }^{-1}$ of Pseudo-nitzschia spp. in the innermost parts of the Ría on 28 May 2007 that declined to $5 \times 10^{5}$ cells L ${ }^{-1}$ ( 4 June) and $3.2 \times 10^{5}$ cells L ${ }^{-1}$ (11 June) over the following 2 weeks (Fig. 7).

On board observations of plankton net hauls and pump concentrates revealed a microplankton community dominated by Pseudo-nitzschia species accompanied by large centric chain-forming diatoms (e.g. Detonula pumila). Only scattered cells of Dinophysis acuminata, D. ovum and D. rotundata were occasionally observed in the warmer surface layers throughout the cruise, although D. acuminata peaked $\left(7 \times 10^{3}\right.$ cells $\left.\mathrm{L}^{-1}\right)$ three weeks later. 
Microphytoplankton analyses showed the co-occurrence of two groups of Pseudo-nitzschia species: $P$. seriata and $P$. delicatissima. The $P$. seriata group, with a dominance of $P$. australis, the main DA producer in the Galician Rías, was more abundant than that of P. delicatissima throughout the cruise (Fig. 8). A maximum of $2 \times 10^{6}$ cells $\mathrm{L}^{-1}$ of the $P$. seriata group was recorded on 29 May at station 2 (Fig. 8A). P. seriata group exhibited a significant decline from 31 May to 5 June in all stations, followed by a moderate increase on 7 June (Figs. 8B-F). In the same way, maximum densities of $6.6 \times 10^{5}$ cells $\mathrm{L}^{-1}$ of the $P$. delicatissima group were observed on 31 May 2007 (Fig. 8H); a significant decline was observed during the days (1-5) June, and a moderate increase led to maximum densities of $1.8 \times 10^{5}$ cells $\mathrm{L}^{-1}$ by the end of the survey $(8$ June) (Figs. 8I-L).

Although the distribution of the two groups of Pseudo-nitzschia showed similar temporal patterns, $P$. delicatissima group showed higher cells densities at stations closer to the mouth of the Ría (stations 3 and 4).

\subsection{Thin layer dynamics}

Vertical profiles of fluorescence at station 2 revealed the occurrence of thin layers. The fluorescence profile and thin layers varied with the tide and with the variability induced by wind events (see section 3.4). On 29 May under downwelling conditions a thin layer dominated by the Pseudo-nitzchia seriata group was observed. The thin layer chl- $a$ maximum $\left(14.5 \mu \mathrm{g}\right.$ equiv. $\mathrm{L}^{-}$

${ }^{1}$ ) was between 18 and $19 \mathrm{~m}$ in the $27 \sigma_{\mathrm{t}}$ isopycnal (Fig. 9A). Southerlies caused a vertical displacement of a weakened (6.5 $\mu$ g equiv. $\mathrm{L}^{-1}$ ) thin layer to $25 \mathrm{~m}$ depth on 30 May (Fig. 9B) and its further erosion from 2 to 4 June (Fig. 9C and D). A new thin layer was found in the upper water column under the upwelling pulse during the second half of the cruise, reaching its 
maximum definition (17.2 $\mu \mathrm{g}$ equiv. $\mathrm{L}^{-1}$ at $\left.11-12 \mathrm{~m}\right)$ on 7 June and again associated with the 27 $\sigma_{\mathrm{t}}$ isopycnal (Fig. 9E-F). This new thin layer was dominated by the Pseudo-nitzchia seriata group with a maximum cell density of $6.5 \times 10^{3}$ cells $\mathrm{L}^{-1}$.

\subsection{Circadian variability in the distribution of Pseudo-nitzschia spp.}

The $P$. seriata group was dominant most of the time in the two cycle studies. The first $24-\mathrm{h}$ cycle (29-30 May) was carried out under downwelling conditions and increasing tides after the neap tide on 25 May. A thin layer (max. $14.5 \mu \mathrm{g}$ chl- $a$ equiv. $\mathrm{L}^{-1}$ ) was observed at $20 \mathrm{~m}$ in the beginning of the cycle (1800, ebb tide) (Fig. 10A) and the maximum density $\left(1.7 \times 10^{6}\right.$ cells L $\left.^{-1}\right)$ of the $P$. seriata group, $2 \mathrm{~h}$ later at $15 \mathrm{~m}$ depth (Fig. 10B). After 2200 when flood tide began, the thin layer was eroded and the chlorophyll maximum followed the excursions of the pycnocline (Figs. 10C-L). The P. delicatissima group, almost under detection levels in the first half of the

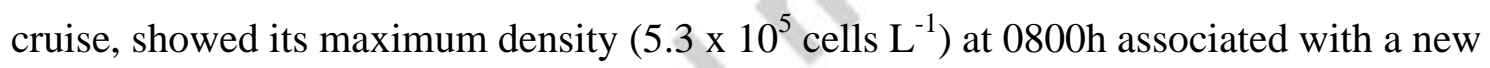
chlorophyll maximum at $17 \mathrm{~m}($ Fig. 10H) and exceeded that of the $P$. seriata group at noon (Fig. 10J). By the end of the cycle (end of the ebb) there was an almost homogenous distribution of chl- $a$ within the water column and a moderate maximum of P. seriata group below $20 \mathrm{~m}$ (Fig. 10L).

The second cycle (6-7 June) was carried out under upwelling relaxation and strong tides following the spring tide on the preceding day. Maximum cell densities of the P. seriata $\left(6.5 \times 10^{5}\right.$ cells $\left.\mathrm{L}^{-1}\right)$ and $P$. delicatissima $\left(1.7 \times 10^{5}\right.$ cells $\left.\mathrm{L}^{-1}\right)$ groups were lower than in the first cycle. At the beginning (0800h), a homogenous distribution of chl- $a$ and low cell densities of the two Pseudo-nitzschia groups were observed (Fig. 11A). In a contrasting sequence with the first cycle, here increased chl- $a$ heterogeneities were observed after $1200 \mathrm{~h}$ and a thin layer $(\sim 17 \mu \mathrm{g}$ 
equiv. $\left.\mathrm{L}^{-1} ; 11 \mathrm{~m}\right)$ appeared at $0000 \mathrm{~h}$ associated with $P$. seriata cells maximum (Figs. 11I). Similar to the first 24-h cycle, the chlorophyll maximum followed the excursions of the pycnocline (Fig. 11).

\subsection{Toxins}

Despite the predominance of $P$. australis in most samples tested, domoic acid in water and particulate samples was always under the detection level $\left(0.02 \mu \mathrm{g} \mathrm{DA} \mathrm{mL} \mathrm{m}^{-1}\right)$ of the applied method. Similarly, there were no shellfish harvesting closures due to the occurrence of DA in mussels above the regulatory limit in the region during 2007.

\subsection{Satellite imaging of bloom transport and dissipation}

Cold $\left(>15^{\circ} \mathrm{C}\right)$ waters were observed on 26 May around neap tides before the survey. Cloud-free ocean colour images were plotted from 26 May to 11 June 2007 except those corresponding from 29 May to June 5 and between June 7 and 10 that were not clear (Fig. 12). The day pass of the satellite over the study area provides simultaneous values of chl- $a$ and SST MODIS images showed a significant increase in SST from 26 May $\left(\sim 14.5^{\circ} \mathrm{C}\right)$ to 11 June $2007\left(\sim 17.5^{\circ} \mathrm{C}\right)$. MODIS chl- $a$ images at that time revealed high values of chl- $a\left(\sim 10 \mu \mathrm{g}\right.$ equiv. $\left.1^{-1}\right)$ on the adjacent shelf and within Ría de Pontevedra. The next clear images were obtained on 5 June, following the upwelling pulse that started on 3 June. Warmer surface waters were then apparently exported from the rías, as shown in the T-depth evolution (Fig. 2D) and the Scanfish transect on 4 June (Fig. 6D). This agrees with ADCP data showing that maximum velocity and therefore export of surface waters occurred on 5 June. MODIS and MERIS images showed a high chlorophyll zone on the shelf close to the mouth of the Ría. It is important to note that the 
MERIS image from 5 June was obtained during ebb, while those from MODIS correspond to flood tide.

In-situ data (CTD and Scanfish) showed chlorophyll maxima at 15-20 m depth at the mouth of the Ría, which corresponded to the high satellite chlorophyll estimates. During upwelling relaxation on 6 June, when the second daily cycle was sampled, no clear SST images were obtained from the coastal area but the MODIS image showed a decrease of the high chlorophyll area with maximum values north of Ría de Pontevedra. Images on 11 June showed warm waters on the shelf and a high chlorophyll area by the mouths of Ría de Pontevedra and Vigo (Figs. $12 \mathrm{M}$ and $\mathrm{N}$ ). In the middle and inner reaches of Ria de Pontevedra chlorophyll fluorescence was low. This agrees with the decrease of Pseudo-nitzschia spp. densities observed in monitoring sampling in this area on 11 May (Fig. 7).

\subsection{Microphytoplankton assemblages}

PCA analysis of microphytoplankton species abundance extracted three principal components (Table 3; Fig. 13A) that explained 33.6\% of the total variance. Higher cell densities corresponded to Pseudo-nitszchia spp., Leptocylindricus danicus, Detonula pumila and Chaetoceros spp. The first principal component (PC1) explained 14.3\%, the second (PC2) 11.8\%, and the third (PC3) 7.5\% of the variance. PC1 represents changes in microphytoplankton abundance, while PC2 seems to be related to a longitudinal gradient with highest values in the innermost parts of the Ría; PC3 was associated with temporal variability.

PC1 differentiated between a diatom assemblage with the highest positive loads $(>0.23)$ (Stephanopyxis turris, Eucampia zodiacus, Pleurosigma spp., Guinardia striata and Navicula 
spp.) and a dinoflagellates assemblage (Torodinium spp., Scrippsiella spp. and other small thecate dinoflagellates) with negative loads with this component. This component was negatively correlated with temperature and positively correlated with salinity (Fig. 13B). The temporal evolution of the vertical distributions of PC1 scores in a longitudinal transect of the Ría (note that station 4 is to the north of the navigation channel) showed high positive loads in a subsurface layer (10-20 m) on 29 May (Fig. 14A) and also near the bottom ( $\sim 20 \mathrm{~m}$ ) between 2 and 4 June (Figs. 14D and G). Negative values of PC1 were detected in surface layers between 2 June to 4 June, coinciding with the upwelling phase. Heterotrophic dinoflagellates Protoperidinium cf. conicum, Protoperidinium divergens, Pyrocystis lunula and Amphidinium spp. evidenced high positive loads ( $>0.25)$ with PC2, while only five taxa (Gyrodinium spp., Protoperidinium bipes, Nitzschia longissima, several large thecate dinoflagellates and Navicula spp.) showed negative loads with this component (Fig. 13A; Table 3). PC2 was positively correlated with fluorescence (Fig. 13B). The evolution of PC2 was characterized by positive scores restricted to deeper layers, with the highest positive values in the innermost parts of the Ría during the middle of the cruise (Fig. 14E). High positive PC2 values on 2 and 4 June are located in the high chlorophyll area (Fig. 6]).

PC3 differentiated between an assemblage containing the dinoflagellate Gyrodinium spp., small thecate dinoflagellates and diatoms (Detonula pumila, P. seriata and Chaetoceros spp.) (positive score) and another assemblage primarily composed of heterotrophic (Protoperidinium cf. stenii, Amphidinium spp.) and other large thecate dinoflagellates (negative score) (Fig. 13A; Table 3). This component was negatively correlated with temperature and salinity. The evolution of PC3 showed changes from positive to negative 
scores during the transition from downwelling to upwelling, and therefore indicates the switch from diatom to dinoflagellate dominance (Figs. 14C,F and I).

\section{Discussion}

The survey took place during a downwelling-upwelling cycle which had been preceded by an upwelling event. Changes in thermohaline structure and chemical properties of the water column showed a rapid response to wind forcing. The transition of downwelling during the first days of the cruise to upwelling was characterised by low wind intensity and thermal stratification in the top (0-10m) layer. The strong upwelling event from 3 to 5 June led to the inflow of nutrient-rich ENACW waters into the Ría de Pontevedra. This agrees with the downward gradient of the isolines towards the coast intercepting the bottom at the mouth of the Ría under southerlies (1 June) in contrast with the shoreward shoaling of the isolines under northerly winds (4 June) evidenced through the high-resolution Scanfish measurements. The latter hydrodynamic process is a clear indicator of upwelling of denser $\left(\sim 27 \sigma_{\mathrm{t}}\right)$ nutrient-rich ENACW. In addition, the SST satellite images suggested export of surface waters from the Ría. This meteorologicalhydrographic coupling is of particular interest in the Galician Rías Baixas, because upwelling (not river flow) is the primary nutrient source (Fraga, 1981).

\subsection{Spring-neap cycle and wind event associated variability of Pseudo-nitzschia spp.}

Previous studies have shown that the formation, maintenance and dissipation of phytoplankton blooms are the result of physical (horizontal and vertical transport) and biological processes (in situ growth, grazing, parasites and/or virus infection) (Smayda, 1997b, a). Conditions during the decline of Pseudo-nitzschia blooms have received much less attention than those promoting 
their initiation (Lelong et al., 2012). Changes in distribution patterns of Pseudo-nitzschia spp. through the present study were closely coupled to physical process during a downwellingupwelling sequence. Pseudo-nitzschia spp. and in particular the P. seriata group, appeared aggregated in a thin layer at the beginning of the survey (29 May) despite the downward displacement of the water caused by downwelling. This was followed by a decrease in cell densities and a further vertical displacement and erosion of the thin layer during downwelling, before a new thin layer, that reached its maximum definition within the $27 \sigma_{\mathrm{t}}$ isopycnal (corresponding to ENACW), was established under upwelling conditions. The sequence of events and changes in cell distribution patterns suggest that the Pseudo-nitzschia spp. bloom was formed during the previous upwelling event (25-28 May) and neap tide conditions, reflected by the high concentrations of Pseudo-nitzschia spp. $\left(1.2 \times 10^{6}\right.$ cells $\left.\mathrm{L}^{-1}\right)$ recorded (28 May) by the monitoring programme.

Velo-Suárez et al. (2008) illustrated a similar mechanism to explain the accumulation and dispersion of Pseudo-nitzschia spp. in Ría de Pontevedra (NW Spain). These authors described maximum densities of Pseudo-nitzschia spp. $\left(>1.5 \times 10^{6}\right.$ cells $\left.\mathrm{L}^{-1}\right)$ forming thin layers located within a very steep pycnocline $\left(\sim 2 \mathrm{~kg} \mathrm{~m}^{-3} / 10 \mathrm{~m}\right)$ under northerly winds. Sinking and erosion of the thin layer-that included a senescent population of Pseudonitzschia spp.- was then associated with southerlies. These authors carried out their study in the same location and time of the year, but the sequence of hydrodynamic events were the opposite (upwelling-downwelling) from those reported here, and dealing with later stages of the Pseudo-nitzschia bloom that was not reaggregated in a thin layer in the subsequent upwelling pulse. Further, results presented here emphasize the importance of the combined effects of the spring-neap tidal cycle with the wind forcing. 
Advection has been suggested as the main shoreward transport mechanism of Pseudo-nitzschia in Washington waters (Northern California Current System). In that area, high-density populations of Pseudo-nitzschia build up in the anticyclonic Juan de Fuca eddy, a well described structure that acts as a retention area ("incubator"). Thus, onshore winds may cause dispersion of the eddy and transport of the diatom populations to the coast (Adams et al., 2006; Trainer et al., 2002). A similar mechanism may have advected Pseudo-nitzschia spp. from the adjacent shelf into the Rías at the beginning of the downwelling event.

The spring-neap tidal variability of the Pseudo-nitzschia groups was also reflected through MERIS and MODIS satellite images, which recorded high concentrations of chlorophyll on the adjacent shelf and within Ría de Pontevedra during the upwelling pulse and neap tides prior to the survey (26-28 May). Unfortunately no clear images were available to evaluate the surface displacement of chlorophyll during a period of southerly winds (30 May-2 June) due to cloud cover. However, the ADCP moored in the main channel revealed net transport into the Ría (Fig. 4) modulated by tides. In addition, the generation of high chlorophyll offshore jets (chl- $a$ plume) during upwelling combined with spring tides on 5 June could also be detected from satellite images. This agrees with recent studies in the Galician Rías Baixas which concluded that a combination of satellite images (MERIS) and ground truthing (microphytoplankton analyses) during Pseudo-nitzschia spp. blooms allows the tracking of high biomass subsurface blooms of potentially harmful species with this technology (González-Vilas et al., 2011; Spyrakos et al., 2011).

\subsection{Circadian variability of Pseudo-nitzschia spp.}


The circadian variability of $P$. seriata and $P$. delicatissima groups appeared modulated by tidal forcing with a clear semi-diurnal signal, coupled to the larger-scale variability controlled by winds. This coupling of tides and wind effects led to a pattern characterized by maximum cell densities of Pseudo-nitzschia spp. during low tide associated with maximum stratification, and by the rising and sinking of the SCM located in the pycnocline.

The two circadian cycles were studied under similar water level conditions $(\sim 3.7 \mathrm{~m})$, but they showed an inverse temporal pattern of Pseudo-nitzschia distribution. During the first cycle, the Pseudo-nitzschia population formed in the previous week under upwelling conditions declined after the onset of southerly winds. In contrast, during the second cycle, the formation of a new Pseudo-nitzschia maximum was promoted by upwelling pulse. This is a clear example of how the spatial and temporal distribution of Pseudo-nitzschia populations is affected by the interaction of events of different time scales (hours - days).

Tidal forcing has been suggested as a key physical factor controlling the diel variability of various phytoplankton species (Cloern, 1991; Cziesla, 1999; Lauria et al., 1999; Li and Smayda, 2001). Previous studies described tidal forcing effects on the distribution of dinoflagellate communities dominated by Dinophysis species in spring (Velo-Suárez et al., 2009) and autumn (Pizarro et al., 2008). Pizarro et al. (2008) observed that stability during low tide in Ría de Pontevedra promoted the aggregation of Dinophysis acuta in near surface layers, and suggested that tidal forcing was the main factor affecting the circadian variability of this species in the absence of vertical migration. Nevertheless, this short time scale effect has been poorly described for Pseudo-nitzschia populations. Cziesla (1999) studied the variability of Pseudonitzschia spp. in Coos Bay estuary (Oregon, USA) and described a distribution pattern characterized by maximum cell densities during high tide. This author identified tidal advection 
from the adjacent shelf as the main factor controlling the variability of Pseudo-nitzschia spp. distribution in that area. A similar observation was noted by Roegner et al. (2002) who described pulses of chlorophyll entering the Willapa Bay estuary (Oregon, USA) during flood tides reaching maximum concentrations during high tide. In contrast, our results from station 2 , located to the south of the navigation channel, showed a different distribution pattern, with cell maxima appearing during low tides and co-occurring with maximal water column stratification.

\subsection{Microphytoplankton assemblages}

The microphytoplankton assemblages observed during the cruise showed a short-term succession which was characterized by dominance of diatoms (Pseudo-nitzschia spp., Detonula pumila, Leptocylindricus danicus and Chaetoceros spp.) during the first half of the cruise (downwelling phase) and increase of dinoflagellates (mainly Protoperidinium divergens and Amphidinium spp.) during the middle part of the cruise (relaxation phase), and a new increase of diatoms (mainly Pseudo-nitzschia seriata group) at the end of the cruise (upwelling phase). The upwelling-event that took place from 26-28 May, prior to the cruise, may have been responsible for the microphytoplankton community structure (diatom dominated) observed at the beginning of the survey under downwelling conditions. These changes in species composition and abundance were clearly shown by the PCA. Increased diatoms abundance were positively correlated with the colder and saltier upwelling waters, whereas dinoflagellates abundance with warmer and more brackish surface waters. All these changes suggest a rapid transition on a short time scale (days) associated with the downwelling-upwelling cycle. According to Nogueira \& Figueiras (2005), these short-term successions are generated by hydrodynamic changes induced by meteorological disturbances, occur with a periodicity of $2 \pm 1$ weeks within the seasonal 
pattern, impose a short-term temporal structure on the ecosystem, and reflect the $r$ - to $k$-strategy distinction (Margalef, 1978; Smayda and Reynolds, 2001).

Figueiras et al. (1996) suggested that downwelling may remove diatoms from the surface layer. Our results indicate a similar mechanism characterized by sinking of Pseudo-nitzschia population and transport offshore of the subsurface layers during the downwelling event. It is not clear if the exported population during the downwelling cycle returns to the ria during upwelling, although the Scanfish sequence on June 4 and the satellite images on June 5-6 suggest this might be the case. These changes were mainly shown by the $P$. seriata groups, which showed a significant decrease in abundance during downwelling-relaxation phases. In addition, this group showed a high positive load with PC3 associated with temporal variability of the microphytoplankton assemblages.

\subsection{Implications for research and monitoring of HAB events}

Maximum densities of Pseudo-nitzschia spp. observed during the survey were 2-3 times higher than those reported in the same stations from the weekly monitoring hose samples (0-5, 5-10, 10-15 m) in Ría de Pontevedra on 28 May. Large changes in cell density were observed during the survey in response to the transition from downwelling to upwelling and to the spring-neap cycle. Noticeably, changes were observed on time scales of a few hours (tidal scale) and these are usually overlooked in conventional weekly sampling strategies. A good understanding of short-term variability and the physical forcings involved are key aspects for risk assessment of toxic events and the short time scales under which shellfish contamination may occur in coastal waters in upwelling systems. 
Despite a predominance of $P$. australis in the acid-cleaned samples examined, high density populations of Pseudo-nitzschia spp. observed during the cruise were not associated with mussel harvesting closures due to the presence of ASP toxins above regulatory levels. ASP toxins were not detected either in HPLC analyses of plankton samples rich in Pseudo-nitzschia spp. collected during the cruise.

P. australis was first described as a DA producer in the Galician Rías in 1995 (Míguez et al., 1996), and presence of ASP toxins above regulatory levels in the area has always been associated with blooms of this species. Pseudo-nitzschia spp. enumerated with conventional optical microscopy can not be identified to species level (McDonald et al., 2007). Toxic and non-toxic species of Pseudo-nitzschia spp., with the same morphology under the light microscope, may bloom together. Acid treatment allows identification of Pseudo-nitzschia spp. of the seriata group in processed samples at 1000X under oil immersion objective but not quantification. In addition, large differences in toxin content per cell have been observed during different stages of population growth, and maximum values are usually observed in the stationary phase (Bates, 1998; Trainer et al., 2012). Thus, even if the suspected species is identified and quantified with molecular tools, an early stage bloom of the species still may not lead to shellfish intoxication. In this context, several laboratory studies (Bates et al., 1991; Fehling et al., 2004) have identified nutrient stress (silicic acid, phosphorus, iron and copper) as significant factors for toxin production by Pseudo-nitzschia species. The high nutrient concentration observed at the beginning of the cruise coinciding with maximum concentrations of Pseudo-nitzschia spp., in particular P. seriata group (dominated by $P$. australis), may have been responsible for the absence of ASP toxins in shellfish in the Ría de Pontevedra during 2007. In addition, high clonal variability in DA production has been demonstrated for $P$. 
australis and P. multiseries from Monterey Bay, California (Kudela et al., 2003), whereby the occurrence in 2007 of Pseudo-nitzschia strains with different toxigenic potential can not be discarded. For all these reasons, monitoring based on ASP toxin content per volume of water in addition to Pseudo-nitzschia cell counts, as that performed on the U.S. west coast (Trainer and Suddleson, 2005) would be more realistic for seafood safety management.

\section{Conclusions}

Hydrodynamic control is crucial in the formation, transport and dissipation of Pseudo-nitzschia blooms in the Galician Rías Baixas. Upwelling-downwelling cycles and semidiurnal and springneap tides are the main forcing elements that control the distribution of Pseudo-nitzschia populations at time scales of weeks to hours. A sequence of sinking, erosion of a thin layer and formation of a new one was clearly evidenced. Tidal cycles modulate the response of the rías to wind variability. Maximum increases in density of Pseudo-nitzschia spp. in short-scale periods (hours) were associated with maximal stratification during low tide. The absence of ASP toxins in shellfish coinciding with high concentrations of Pseudo-nitzschia spp. dominated by $P$. australis - a species considered as the main agent of ASP events in the Galician Rias Baixasshowed that an alternative monitoring based on ASP toxin content per volume of water in addition to cell counts would be more realistic for seafood safety management. Finally, the results here show the need to consider the high-frequency variability (tidal-scale) in cell densities of potentially toxic species when designing and implementing harmful algal bloom monitoring programmes.

\section{Acknowledgements}

We thank the Galician Monitoring Programme (INTECMAR) for weekly reports on phytoplankton distributions in the Galician Rías Baixas and bathymetry data, and the crew 
of R/V Mytilus for assistance. D. Barton helped with interpretation of Scanfish data, F.G. Figueiras with PCA analyses and S. Fraga with identification of Pseudo-nitzschia spp. S. González-Gil and P. Rial participated in the cruise. The authors thank the NERC Earth Observation Data Acquisition and Analysis Service (NEODAAS) for data supply.for this study. This work was funded by projects: Harmful Algal Bloom Species in Thin Layers (HABIT) from the $6^{\text {th }}$ Framework Programme (HABIT/GOCE-CT-2005-003932) and Applied Simulations and Integrated Modelling for the Understanding of Toxic and Harmful algal blooms (ASIMUTH) from the 7th Framework Programme (ASIMUTH/SPACE-Grant Agreement 261860) of the European Commission. Patricio A. Díaz is supported by a $\mathrm{PhD}$ student fellowship from the BECAS-CHILE Programme of the National Commission for Scientific and Technological Research (CONICYT), Chile. This is a contribution to the SCOR and IOC programme on "Global Ecology and Oceanography of Harmful Algal Blooms (GEOHAB)", Core Research Projects on "HABs and Stratification" and "HABs in Upwelling Systems" (www.geohab.info).

\section{References}

Adams, N.G., MacFadyen, A., Hickey, B.M., Trainer, V.L., 2006. The nearshore advection of a toxigenic Pseudo-nitzschia bloom and subsequent domoic acid contamination of intertidal bivalves. Afr. J. M. Sci. 28, 271-276.

Álvarez-Salgado, X.A., Figueiras, F.G., Pérez, F.F., Groom, S., Nogueira, E., Borges, A.V., Chou, L., Castro, C.G., Moncoiffé, G., Ríos, A.F., Miller, A.E., Frankignoulle, M., Savidge, G., Wollast, R., 2003. The Portugal coastal counter current off NW Spain: new insights on its biogeochemical variability. Prog. Oceanogr. 56, 281- 321.

Álvarez-Salgado, X.A., Figueiras, F.G., Fernández-Reiriz, M.J., Labarta, U., Peteiro, L.,

Piedracoba, S., 2011. Control of lipophilic shellfish poisoning outbreaks by seasonal upwelling and continental runoff. Harmful Algae 10, 121-129.

Aminot, A., Kerouel, R., 2007. Dosage automatique des nutriments dans les eaux marines: méthodes en flux continu. Ifremer.

Bakun, A., 1973. Coastal Upwelling Indices, West Coast of North America, 1946-71, U.S. Dep. Commer., NOAA Technical Report, NMFS SSRF-671. 
Bates, S.S., Bird, C.J., De Freitas, A.S.W., Foxall, R., Gilgan, M.W., Hanic, L.A., Johnson, G.E., Mcculloch, A.W., Odense, P., Pocklington, R.G., Quillan, M.A., Sim, P.G., Smith, J.C., V., S.R.D., Todd, E.C.D., Walter, J.A., Wright, J.L.C., 1989. Pennate diatom Nitzschia pungens as the primary source of domoic acid, a toxin in shellfish from eastern Prince Edward Island, Canada. Can. J. Fish. Aquat. Sci. 46, 1203-1215.

Bates, S.S., de Freitas, A.S.W., Miley, J.E., Pocklington, R., Quilliam, M.A., Smith, J.C., Worms, J., 1991. Controls on domoic acid production by the diatom Nitzschia pungens $\mathrm{f}$. multiseries in culture: nutrients and irradiance. Can. J. Fish. Aquat. Sci. 48, 1136-1144.

Bates, S.S., 1998. Ecophysiology and metabolism of ASP toxin production, in: Anderson, D.M., Cembella, A.D., Hallegraeff, G.M. (Eds.), Physiological Ecology of Harmful Algal Blooms. Springer-Verlag Berlin Heidelberg, Berlin Heidelberg, pp. 405-426.

Blanton, J.O., Atkinson, L.P., Castillejo, F., Lavin, A., 1984. Coastal upwelling off Rías Bajas, Galicia, Northwest Spain I: Hydrographic studies. Rapp P V Réun Cons int Explor Mer $183,79-90$.

Cloern, J., Powell, T., Huzzey, L., 1989. Spatial and temporal variability in South Say (USA). 11. Temporal San Francisco changes in salinity, suspended sediments, and phytoplankton biomass and productivity over tidal time scales. Estuar. Coast. Shelf. Sci. 28, 599-613.

Cloern, J.E., 1991. Tidal stirring and phytoplankton bloom dynamics in an estuary. J. Mar. Res. 49, 203-221.

Cziesla, C.A., 1999. The transport and distribution of the toxic diatom Pseudo-nitzschia spp. in the Coos Bay estuary and the adjacent continetal shelf, Departament of Biology. Master dissertation, University of Oregon, Eugene, OR, Oregon, p. 98. 
Chase, J., 1975. Wind-driven circulation in a Spanish estuary. Estuar. Coast. Mar. Sci. 3, 303310.

de Castro, M., Gómez-Gesteira, M., Prego, R., Taboada, J.J., Montero, P., Herbello, P., PérezVillar, V., 2000. Wind and Tidal Influence on Water Circulation in a Galician Ria (NW Spain). Estuar. Coast. Shelf. Sci. 51, 161-176.

Doerffer, R., Schiller, H., 2007. The MERIS Case 2 water algorithm. Int. J. Remote Sens. 28, $517-535$.

Escalera, L., Reguera, B., Moita, T., Pazos, Y., Cerejo, M., Cabanas, J.M., Ruiz-Villarreal, M., 2010. Bloom dynamics of Dinophysis acuta in an upwelling system: In situ growth versus transport. Hamrful Algae 9, 312-322.

FAO, 2012. The state of world fisheries and aquaculture. FAO Fisheries and Aquaculture Department, Rome, Italy.

Fawcett, A., Pitcher, G., Bernard, S., Cembella, A., Kudela, R., 2007. Contrasting wind patterns and toxigenic phytoplankton in the southern Benguela upwelling system. Mar. Ecol. Prog. Ser. 348, 19-31.

Fehling, J., Davis, C.S., Bolch, C., Bates, S., 2004. Growth and domoic acid production by Pseudo-nitzschia seriata (Bacillariophyceae) under phosphate and silicate limitation. J. Phycol. 40, 674-683.

Figueiras, F.G., Ríos, A.F., 1993. Phytoplankton succession, red tides and the hydrographic regime in the Rias Bajas of Galicia., in: Smayda, T.J., Shimizu, Y. (Eds.), Toxic Phytoplankton Blooms in the Sea. Elsevier, Amsterdam, pp. 239-244.

Figueiras, F.G., Gómez, E., Nogueira, E., Villarino, M.L., 1996. Selection of Gymnodinium catenatum under downwelling conditions in the Ría de Vigo, in: Yasumoto, T., Oshima, 
Y., Fukuyo, Y. (Eds.), Harmful and Toxic Algal Blooms. Intergovernmental Oceanographic Commission of UNESCO, Sendai, Japan., pp. 215-218.

Figueiras, F.G., Labarta, U., Fernández Reiriz, M.J., 2002. Coastal upwelling, primary production and mussel growth in the Rías Baixas of Galicia. Hydrobiologia 484, 121131.

Fraga, F., 1981. Upwelling off the Galician coast, Northwest Spain, in: Richards, F.A. (Ed.), In Coastal Upwelling. American Geophysical Union, Washington, pp. 176-182.

Fraga, S., Alvarez, M.J., Míguez, Á., Fernández, M.L., Costas, E., López-Rodas, V., 1998. Pseudo-nitzschia species isolated from Galician waters: toxicity, DNA content and lectin binding assay, in: Reguera, B., Blanco, J., Fernández, M.L., Wyatt, T. (Eds.). Harmful Algae, Xunta de Galicia. IOC UNESCO, pp. 270-273.

Fryxell, G.A., Hasle, G.R., 2002. Taxonomy of harmful diatoms, in: Hallegraeff, G.M., Anderson, D.M., Cembella, A.D. (Eds.), Manual on harmful marine microalgae. monographs on oceanographic methodology 11. UNESCO Publishing, France, pp. 465509.

Furey, A., Lehane, M., Gillman, M., Fernández-Puente, P., James, K.J., 2001. Determination of domoic acid in shellfish by liquid chromatography with electrospray ionization and multiple tandem mass spectrometry. J. Chromatogr. 938, 167-174.

Gentien, P., Lunven, M., Lehaitre, M., Duvent, J.L., 1995. In situ depth profiling of particles sizes. Deep Sea Res. I 42, 1297-1312.

GEOHAB, 2005. Global Ecology and Oceanography of Harmful Algal Blooms, in: Pitcher, G., Moita, T., Trainer, V., Kudela, R., Figueiras, F., Probyn, T. (Eds.), IOC and SCOR, GEOHAB Core Research Project: HABs in Upwelling Systems. 82, Paris and Baltimore. 
González-Vilas, L., Spyrakos, E., Torres-Palenzuela, J., 2011. Neural network estimation of chlorophyll $a$ from MERIS full resolution data for the coastal waters of Galician rias (NW Spain). Remote Sens. Environ. 115, 524-535.

Hasle, G.R., 1965. Nitzschia and Fragilariopsis species studied in the light and electron microscopes. II. The group Pseudo-nitzschia. Skr norske Vidensk Akad I Mat Nat Kl NS 18

Hasle, G.R., Syvertsen, E.E., 1996. Marine diatoms, in: Tomas, C.R. (Ed.), Identifying Marine Diatoms and Dinoflagellates. Academic Press, New York, pp. 5-385.

Kudela, R., Roberts, A., Armstrong, M., 2003. Laboratory analyses of nutrient stress and toxin production in Pseudo-nitzschia spp. from Monterey Bay, California, in:

Steidenger, K.A., Landsberg, J.H., Tomas, C.R., Vargo, G.A. (Eds.), Harmful algae 2002. Florida and Wildlife Conservation Commission, Florida Institute of Oceanography, and Intergovernmental Oceanographic Commission of UNESCO, St. PeteBeach, FL, pp. 136138.

Lauria, M.L., Purdie, D., Sharples, J., 1999. Contrasting phytoplankton distributions controlled by tidal turbulence in an estuary. J. Marine Syst. 21, 189-197.

Lelong, A., Hégaret, H., Soudant, P., Bates, S.S., 2012. Pseudo-nitzschia (Bacillariophyceae) species, domoic acid and amnesic shellfish poisoning: revisiting previous paradigms. Phycologia 51, 168-216.

Li, Y., Smayda, T., 2001. A chlorophyll time series for Narragansett Bay: Assessment of the potential effect of tidal phase on measurement. Estuaries 24, 328-336. 
Lindahl, O., 1986. A dividable hose for phytoplankton sampling. Report of the working group on phytoplankton and management of their effects. International Council for the Exploration of the Sea, C.M.1986/L: 1926, annex 1983.

Lovegrove, T., 1960. An improved form of sedimentation apparatus for use with an inverted microscope. J. Cons. Int. Explor. Mer. 25, 279-284.

Lundholm, N., 2012. IOC-UNESCO Taxonomic Reference List of Harmful Micro Algae. Available online at http://www.marinespecies.org/HAB (accessed 15 February 2013).

Lunven, M., Guillaud, J.F., Youenou, A., Crassous, M., Berric, R., Le Gall, E., Kerouel, R., Labry, C., Aminot, A., 2005. Nutrient and phytoplankton distribution in the Loire river plume (Bay of Biscay, France) resolved by a new Fine Scale Sampler. Estuar. Coast. Shelf. Sci. 65, 94-108.

Margalef, R., Duran, M., Saiz, F., 1955. El fltoplancton de la ria de Vígo de enero de 1953 a marzo de 1954. Investigación Pesquera 2, 85-129.

Margalef, R., 1978. Life forms of phytoplankton as survival alternatives in an unstable environment. Oceanol. Acta 1, 493-509.

McClain, C., Chao, S., Atkinson, L., Blanton, J., Castillejo, F., 1986. Wind-driven upwelling in the vicinity of Cape Finisterre, Spain. J. Geophys. Res. 91, 8470-8486.

McDonald, S.M., Sarno, D., Zingone, A., 2007. Identifying Pseudo-nitzschia species in natural samples using genus-specific PCR primers and clone libraries. Harmful Algae 6, 849860.

McManus, M.A., Alldredge, A.L., Barnard, A.H., Boss, E., Case, J.F., Cowles, T.J., Donaghay, P.L., Eisner, L.B., Gifford, D.J., Greenlaw, C.F., Herren, C.M., Holliday, D.V., Johnson, D., 
MacIntyre, S., McGehee, D.M., Osborn, T.R., Perry, M.J., Pieper, R.E., Rines, J.E.B., Smith, D.C., Sullivan, J.M., Talbot, M.K., Twardowski, M.S., Weidemann, A., Zaneveld, J.R., 2003. Characteristics, distribution and persistence of thin layers over a 48 hour period. Mar. Ecol. Prog. Ser. 261, 1-19.

Míguez, A., Fernández, M.L., Fraga, S., 1996. First detection of Domoic Acid in Galicia (NW of Spain), in: Yasumoto, T., Oshima, Y., Fukuyo, Y. (Eds.), Harmful and Toxic Algal Blooms. Intergovernmental Oceanographic Commission of UNESCO 1996, pp. 143145.

Moore, T.S., Campbell, J.W., Dowell, M.D., 2009. A class-based approach to characterizing and mapping the uncertainty of the MODIS ocean chlorophyll product. Remote Sens. Environ. 113, 2424-2430.

Nogueira, E., Pérez, F.F., Ríos, A.F., 1997. Seasonal patterns and long-term trends in an estuarine upwelling ecosystem (Ría de Vigo, NW Spain). Estuar. Coast. Shelf. Sci. 44, 285-300.

Nogueira, E., Figueiras, F.G., 2005. The microplankton succession in the Ría de Vigo revisited: species assemblages and the role of weather-induced, hydrodynamic variability. J. Marine Syst. 54, 139- 155.

Pitcher, G.C., Figueiras, F.G., Hickey, B.M., Moita, M.T., 2010. The physical oceanography of upwelling systems and the development of harmful algal blooms. Prog. Oceanogr. 85, 5-32.

Pitcher, G.C., 2012. Harmful algae-The requirement for species-specific information Hamrful Algae 14, 1-4. 
Pizarro, G., Escalera, L., González-Gil, S., Franco, J., Reguera, B., 2008. Growth, behaviour and cell toxin quota of Dinophisis acuta during a daily cycle. Mar. Ecol. Prog. Ser. 353, 89105.

Prego, R., Dale, A.W., De Castro, M., Gómez-Gesteira, M., Taboada, J.J., Montero, P., RuizVillareal, M., Pérez-Villar, V., 2001. Hydrography of the Pontevedra Ría: Intra-annual spatial and temporal variability in a Galician coastal system (NW Iberia). J. Geophys. Res. 106, 19845-19857.

Quilliam, M.A., Sim, P.G., McCulloch, A.W., McInnes, A.G., 1989. High-performance liquid chromatography of domoic acid, a marine neurotoxin, with application to shellfish and plankton. International Journal of Environmental Analytical Chemistry 36, 139154.

R Development Core Team, 2012. R: A language and environment for statistical computing, R Foundation for Statistical Computing, Vienna, Austria. ISBN 3-900051-07-0, URL http://www.r-project.org/.

Reguera, B., Escalera, L., Pazos, Y., Moroño, A., 2008. Episodios de fitoplancton tóxico en la Ría de Vigo, in: González-Garcés, A., Vilas, F., Álvarez-Salgado, X.A. (Eds.), La Ría de Vigo: Una aproximación integral al ecosistema marino de la Ría de Vigo. Instituto de estudios vigueses, Vigo, pp. 155-199.

Rines, J., Donaghay, P., Dekshenieks, M., Sullivan, J., Twardowski, M., 2002. Thin layers and camouflage: Hidden Pseudo-nitzschia spp. (Bacillariophyceae) populations in a fjord in the San Juan Islands, Washington, USA. Mar. Ecol. Prog. Ser. 225, 123-137. 
Rodríguez, F., Pazos, Y., Maneiro, J., Zapata, M., 2003. Temporal variation in phytoplankton assemblages and pigment composition at a fixed station of the Ria of Pontevedra (NW Spain). Estuar. Coast. Mar. Sci. 58, 499-515.

Roegner, G.C., Hickey, B.M., Newton, J.A., Shanks, A., Armstrong, D.A., 2002. Wind-induced plume and bloom intrusions into Willapa Bay, Washington. Limnol. Oceanogr. 47, 1033-1042.

Ruiz-Villarreal, M., Montero, P., Taboada, J.J., Prego, R., Leitao, P.C., Perez-Villar, V., 2002. Hydrodynamic model study of the Ria de Pontevedra under estuarine conditions. Estuar. Coast. Shelf. Sci. 54, 101-113.

Salgado, C., Maneiro, J., Correa, J., Pérez, J.L., Arévalo, F., 2003. ASP biotoxins in scallops: the practical application in Galicia of Commission Decision 2002/226/EC, in: Villalba, A., Reguera, B., Romalde, J.L., Beiras, R. (Eds.), Molluscan Shellfish Safety. Xunta de Galicia - Intergovernmental Oceanographic Commission of UNESCO, Vigo, pp. 169-177.

Scholin, C., Gulland, F., Doucette, G., Benson, S., Busman, M., Chavez, F., Cordarok, J., DeLong, R., Vogelaere, A., Harvey, J., Haulena, M., LefebvreI, K., Lipscomb, T., Loscutoff, S., Lowenstine, L., Marin, R., Miller, P., McLellan, W., Moeller, P., Powell, C., Rowleskk, T., Silvagni, P., Silver, M., Spraker, T., Trainer, V., Van Dolah, F., 2000. Mortality of sea lions along the central California coast linked to a toxic diatom bloom. Nature 403, 8084.

Shutler, J.D., Land, P.E., Smyth, T.J., Groom, S.B., 2007. Extending the MODIS 1 km ocean colour atmospheric correction to the MODIS 500m bands and 500m chlorophyll- $a$ estimation towards coastal and estuarine monitoring. Remote Sens. Environ. 107, 521-532, doi:510.1016/j.rse.2006.1010.1004. 
Sierra-Beltrán, A.S., Palafox-Uribe, M., Grajales-Montiel, J., Cruz-Villacorta, A., Ochoa, J.L., 1997. Sea bird mortality at cabo san lucas mexico: Evidence that toxic diatom blooms are spreading. Toxicon 35, 447-453.

Smayda, T., 1997a. Harmful algal blooms: Their ecophysiology and general relevance to phytoplankton blooms in the sea. Limnol. Oceanogr. 42, 1137-1153.

Smayda, T., 1997b. Bloom dynamics: Physiology, behavior, trophic effects. Limnol. Oceanogr. 42, 1132-1136.

Smayda, T., Reynolds, C., 2001. Community assembly in marine phytoplankton: application ofrecent models to harmful dinoflagellate blooms. J. Plankton Res. 23, 447-461.

Spyrakos, E., González-Vilas, L., Torres-Palenzuela, J., Barton, E.D., 2011. Remote sensing chlorophyll $a$ of optically waters (rías Baixas, NW Spain): Application of a regionally specific chlorophyll $a$ algorithm for MERIS full resolution data during an upwelling cycle. Remote Sens. Environ. 115, 2471-2485.

Torres, R., Barton, E.D., Miller, P., Fanjul, E., 2003. Spatial patterns of wind and sea surface temperature in the galician upwelling region. J. Geophys. Res. 108, 3130, doi:3110.1029/2002JC001361.

Trainer, V.L., Adams, N., Bill, B., Stehr, C., Wekell, J., Moeller, P., Busman, M., Woodruff, D., 2000. Domoic acid production near California coastal upwelling zones, June 1998. Limnol. Oceanogr. 45, 1818-1833.

Trainer, V.L., Hickey, B., Horner, R., 2002. Biological and physical dynamics of domoic acid production off the Washington coast. Limnol. Oceanogr. 47, 1438-1446.

Trainer, V.L., Suddleson, M., 2005. Monitoring approaches for early warning of domoic acid events in Washington State. Oceanography 18, 228-237. 
Trainer, V.L., Pitcher, G.C., Reguera, B., Smayda, T.J., 2010. The distribution and impacts of harmful algal bloom species in eastern boundary upwelling systems. Prog. Oceanogr. $85,33-52$.

Trainer, V.L., Bates, S., Lundholm, N., Thessen, A., Cochlan, W., Adams, N., Trick, C., 2012. Pseudo-nitzschia physiological ecology, phylogeny, toxicity, monitoring and impacts on ecosystem health. Hamrful Algae 14, 271-300.

Uthermöhl, H., 1958. Zur Vervollkomnung der quantitativen Phytoplankton-Methodik. Mitt. Int. Ver. Limnol. 9, 1-38.

Varela, M., Prego, R., Pazos, Y., 2004. Vertical biogenic particle flux in a western Galician ria (NW Iberian Peninsula). Mar. Ecol. Prog. Ser. 260, 17-32.

Varela, M., Prego, R., Pazos, Y., 2008. Spatial and temporal variability of phytoplankton biomass, primary production and community structure in the Pontevedra Ria (NW Iberian Peninsula): oceanographic periods and possible response to environmental changes. Mar. Biol. 154, 483-499.

Varela, R., Rosón, G., Herrera, J.L., Torrez-López, S., Fernández-Romero, A., 2005. A general view of the hydrographic and dynamical patterns of the Rías Baixas adjacent sea area. J. Marine Syst. 54, 97-113.

Velo-Suárez, L., González-Gil, S., Gentien, P., Lunven, M., Bechemin, B., Fernand, L., Raine, R., Reguera, B., 2008. Thin layers of Pseudo-nitzschia spp. and the fate of Dinophysis acuminata during an upwelling-downwelling cycle in a Galician Ría. Limnol. Oceanogr. $53,1816-1834$ 
Velo-Suárez, L., Reguera, B., Garcés, E., Wyatt, T., 2009. Vertical distribution of division rates in coastal dinoflagellate Dinophysis spp. populations: implications for modelling. Mar. Ecol. Prog. Ser. 385, 87-96.

Velo-Suárez, L., Fernand, L., Gentien, P., Reguera, B., 2010. Hydrodynamic conditions associated with the formation, maintenance and dissipation of a phytoplankton thin layer in a coastal upwelling system. Cont. Shelf. Res. 30, 193-202.

Wooster, W.S., Bakun, A., McLain, D.R., 1976. The seasonal upwelling cycle along the eastern boundary of the North Atlantic. J. Mar. Res. 34, 131- 141.

Work, T.M., Beale, A.M., Fritz, L., Quilliam, M.A., Silver, M., Buck, K., Wright, J.L.C., 1993.

Domoic acid intoxication of brown pelicans and cormorants in Santa Cruz, California, in: Smayda, T.J., Shimizu, Y. (Eds.), Toxic Phytoplankton Blooms in the Sea. Elsevier, Amsterdam, pp. 643-649.

Zapata, M., Rodríguez, F., Fraga, S., Barra, L., Ruggiero, M.V., 2011. Chlorophyll c pigment patterns in 18 species (51 strains) of the genus Pseudo-nitzschia (Bacillariophyceae). J. Phycol. 47, 1274-1280.

Table 1. Potentially toxic species of Pseudo-nitzschia reported in the Galician Rías Baixas (NW Spain).

\begin{tabular}{lll}
\hline Group & Species & Reference \\
\hline seriata & Pseudo-nitzschia australis Frenguelli* & Fraga et al. (1998), Velo-Suárez et al. \\
& & (2008), Zapata et al. (2011) \\
& P. fraudulenta (Cleve) Hasle & Fraga et al. (1998), Zapata et al. (2011) \\
& P. seriata (Cleve) Peragallo & Varela et al. (2008) \\
& P. pungens (Grunow) Hasle & Fraga et al. (1998), Zapata et al. (2011) \\
& P. multiseries (Hasle) Hasle & Fraga et al. (1998) \\
\cline { 2 - 3 } delicatissima & P. delicatissima (Cleve) Heiden & Fraga et al. (1998), Rodríguez et al. \\
& & (2003), Varela et al. (2008), Zapata et al. \\
& & (2011) \\
& $\begin{array}{l}\text { P. pseudodelicatissima (Hasle) Hasle } \\
\text { emend. Lundholm, Hasle et Moestrup }\end{array}$ & Velo-Suárez et al. (2008) \\
& P. cuspidata (Hasle) Hasle emend. & Fraga et al. (1998), Zapata et al. (2011) \\
Lundholm, Moestrup \& Hasle & \\
\hline
\end{tabular}


* Species of Pseudo-nitzschia proven to produce domoic acid (DA) in cultures of strains isolated from the Galician Rias Baixas.

Table 2. Chart of dates, stations, and samples for different purposes collected in Ría de Pontevedra during the survey.

\begin{tabular}{lrrrr}
\hline & \multicolumn{2}{c}{ Sampling stations } & \multirow{2}{*}{ Scanfish track } \\
\cline { 2 - 5 } & $\begin{array}{l}\text { Dicrophytoplankto } \\
\mathrm{n}\end{array}$ & Nutrients & Toxins & \\
\hline May 28 & $1,2^{*}, 3,4$ & & & Ría de Pontevedra \\
May 29 & $2^{*}$ & 2 & 2 & Ría de Pontevedra \\
May 30 & $1,3,4,5$ & 5 & & Ría de Pontevedra \\
May 31 & & & & Ría to adjacent shelf \\
June 1 & $1,2,3,4,6$ & 1,3 & 4 & \\
June 2 & $1,2,3,4$ & 3 & 1,3 & Ría to adjacent shelf \\
June 4 & $1,3,4$ & 4 & 4 & \\
June 5 & $2^{*}$ & 2 & 2 & \\
June 6 & $2^{*}, 4$ & & & \\
June 7 & & & & \\
\hline
\end{tabular}

${ }^{*}$ Stations where 24 -h cycle studies were carried out.

Table 3. Groups and codes, frequency of presence, mean values (cells $\mathrm{L}^{-1}$ ), maximum concentration (cells $\mathrm{L}^{-1}$ ), and scores for the first 3 principal components (PC1-PC3) of the 44 species and taxa selected (those present in $>20 \%$ of the samples) for principal component analysis. Species and taxa were ordered according to their PC1 score. Highest positive and negative scores for PC2 and PC3 are indicated in bold.

\begin{tabular}{llllrrrrr}
\hline Species - taxa & Group & Code & Presence & Mean & Maximum & PC 1 & PC 2 & PC 3 \\
\hline Stephanopyxis turris & Diat & Stur & 68 & 1415 & 19666 & 0.32 & 0.09 & 0.09 \\
Eucampia zodiacus & Diat & Ezod & 79 & 6477 & 107409 & 0.31 & 0.13 & 0.04 \\
Pleurosigma spp. & Diat & Pspp & 57 & 216 & 1536 & 0.29 & 0.05 & 0.03 \\
Guinardia striata & Diat & Gstr & 91 & 12292 & 121024 & 0.28 & 0.13 & -0.05 \\
Navicula spp. & Diat & Nspp & 27 & 125 & 1152 & 0.23 & -0.06 & -0.09 \\
Odontella spp. & Diat & Ospp & 30 & 91 & 400 & 0.19 & 0.06 & 0.16 \\
Thecate dinoflagellates (large) & Dino & Tdinl & 33 & 578 & 2760 & 0.19 & -0.05 & -0.30 \\
Oxytoxum spp. & Dino & Oxsp & 76 & 153 & 1000 & 0.19 & 0.16 & -0.13 \\
Meunieria membranacea & Diat & Mmem & 56 & 252 & 2200 & 0.18 & 0.16 & -0.12 \\
& & & & 27371 & & & & \\
Pseudo-nitzschia seriata group & Diat & Pser & 99 & 7 & 2081613 & 0.18 & 0.17 & 0.26 \\
Protoperidinium bipes & Dino & Prbi & 76 & 320 & 2560 & 0.17 & -0.01 & -0.13 \\
& & & & 13824 & & & & \\
Detonula pumila & Diat & Dpum & 98 & 5 & 1415981 & 0.12 & 0.14 & $\mathbf{0 . 2 8}$ \\
$\begin{array}{l}\text { Proboscia alata } \\
\text { Pseudo-nitzschia delicatissima } \\
\text { group }\end{array}$ & Diat & Pala & 70 & 149 & 768 & 0.12 & 0.23 & -0.03 \\
Protoperidinium leonis & & & & & & & & \\
Protoperidinium mite & Diat & Pdels & 62 & 62271 & 527967 & 0.12 & 0.15 & -0.04 \\
Nitzschia longissima & Dino & Prle & 51 & 92 & 320 & 0.09 & 0.20 & -0.07 \\
Rhizosolenia shrubsolei & Dino & Pmic & 46 & 80 & 280 & 0.08 & 0.12 & 0.12 \\
Amphidinium spp. & Diat & Nlon & 24 & 846 & 12102 & 0.06 & -0.02 & 0.12 \\
& Diat & Rshr & 82 & 246 & 1920 & 0.06 & 0.14 & -0.02 \\
& Dino & Aspp & 96 & 1615 & 17520 & 0.03 & $\mathbf{0 . 2 5}$ & -0.22
\end{tabular}




\begin{tabular}{lllrrrrrr} 
Protoperidinium brevipes & Dino & Prbr & 57 & 97 & 520 & 0.03 & 0.04 & -0.12 \\
Protoperidinium divergens & Dino & Prdiv & 86 & 210 & 1000 & 0.03 & $\mathbf{0 . 2 8}$ & -0.04 \\
Protoperidinium spp. (medium) & Dino & Prspm & 52 & 84 & 360 & 0.03 & 0.11 & -0.02 \\
Gyrodinium spp. (large) & Dino & Gyspl & 66 & 157 & 1800 & 0.02 & 0.12 & $\mathbf{0 . 3 3}$ \\
Gyrodinium spp. (small) & Dino & Gysps & 37 & 169 & 3840 & 0.02 & -0.01 & 0.02 \\
Corythodinium spp. & Dino & Cospp & 30 & 51 & 160 & 0.00 & 0.06 & -0.11 \\
Protoperidinium depressum & Dino & Prde & 21 & 63 & 160 & 0.00 & 0.16 & -0.07 \\
Protoperidinium spp. (small) & Dino & Prspp & 25 & 76 & 320 & 0.00 & 0.15 & 0.09 \\
Pronoctiluca sp & Dino & Prsp & 46 & 64 & 240 & -0.01 & 0.01 & -0.19 \\
Protoperidinium cf. conicum & Dino & Prco & 61 & 142 & 520 & -0.04 & $\mathbf{0 . 2 9}$ & 0.04 \\
Diplopsalis spp. & Dino & Dspp & 81 & 188 & 1920 & -0.05 & 0.21 & 0.17 \\
Gymnodinium spp. & Dino & Gymsp & 96 & 1679 & 9120 & -0.07 & 0.19 & -0.15 \\
Cochlodinium spp. & Dino & Cosp & 28 & 88 & 440 & -0.08 & 0.13 & 0.09 \\
Ceratium furca & Dino & Cfur & 25 & 67 & 320 & -0.10 & 0.15 & -0.16 \\
Gyrodinium spp. (medium) & Dino & Gyspm & 80 & 202 & 960 & -0.11 & 0.07 & 0.05 \\
Protoperidinium cf. stenii & Dino & Prst & 53 & 156 & 640 & -0.12 & 0.11 & $\mathbf{- 0 . 2 5}$ \\
Chaetoceros spp. & & & & 10299 & & & & \\
Ceratium fusas & Diat & Chsp & 100 & 5 & 470481 & -0.13 & 0.13 & $\mathbf{0 . 2 6}$ \\
Ceratium lineatum & Dino & Cfus & 60 & 250 & 2520 & -0.14 & 0.22 & -0.14 \\
Pyrophacus horologicum & Dino & Clin & 34 & 101 & 560 & -0.15 & 0.14 & -0.17 \\
Pyrocystis lunula & Dino & Pyho & 37 & 103 & 360 & -0.15 & 0.10 & 0.14 \\
& Dino & Pylu & 96 & 590 & 7200 & -0.16 & $\mathbf{0 . 2 6}$ & -0.08 \\
Leptocylindricus danicus & & & & 24479 & & & & \\
Scrippsiella spp. & Diat & Ldan & 97 & 4 & 1213266 & -0.18 & 0.18 & 0.18 \\
Thecate dinoflagellates (small) & Dino & Scspp & 95 & 5826 & 47232 & -0.20 & 0.21 & -0.08 \\
Torodinium spp. & Dino & Tdins & 79 & 2863 & 11800 & -0.21 & 0.07 & 0.21 \\
\hline & Dino & Tospp & 48 & 85 & 360 & -0.21 & 0.08 & -0.13 \\
\hline
\end{tabular}

Figures legend

Figure 1. Map of the study area A) Iberian Peninsula; B) Galician Rias Baixas, the Scanfish track and mooring position of the Cabo Silleiro Seawatch buoy (star); C) Ría de Pontevedra and location of the 10 monitoring (INTECMAR) sampling stations (black triangles), 6 cruise sampling stations (black circle) and ADCP mooring. Cruise stations 1, 2 and 4 are common with monitoring stations.

Figure 2. Time series of A) Sea level (m) recorded hourly from 1 May to 12 June 2007 from the tide gauge (IEO Network )at Vigo harbour B) Vector diagram of wind direction and velocity $\left(\mathrm{m} \mathrm{s}^{-1}\right)$ recorded hourly at the Cabo Silleiro Seawatch buoy (negative values correspond to northerly winds), C) Estimated Ekman transport $\left(\mathrm{m}^{3} \mathrm{~s}^{-1} \mathrm{~km}^{-1}\right)$, D) 
temperature $\left.\left({ }^{\circ} \mathrm{C}\right), \mathrm{E}\right)$ salinity and F) chl- $a$ fluorescence ( $\mu$ g equiv. $\mathrm{l}^{-1}$ ) recorded during the survey from 29 May to 7 June 2007 at station 2. The shaded area in the top corresponds to the cruise period.

Figure 3. Changes of current velocity (instantaneous flow) recorded from 29 May to 08 June 2007 at station 3. Sea level (A), the east-west (B) and north-south components (C) are represented.

Figure 4. A) Time series of low-pass filtered wind velocity measured at the Cabo Silleiro Seawatch buoy during the cruise period (negative values correspond to northerly winds); B) Changes of the low-frequency component (30 h) of the current velocity measured at station 3 in the navigation channel from Ria de Pontevedra. White isolines indicate nomotion layers,

Figure 5. Vertical distribution of temperature $\left({ }^{\circ} \mathrm{C}\right.$ ), salinity, chl- $a$ fluorescence ( $\mu$ g equiv. $\mathrm{l}^{-1}$ ) and dissolved nutrients (phosphates, silicates and dissolved inorganic nitrogen - DIN) on A) 30 May and B) 06 June at station 2. These profiles were chosen as the most representative during downwelling (A) and upwelling (B) conditions.

Figure 6. Distributions of A-B) Vertical undulations of the Scanfish between surface waters and the seabed, C-D) temperature $\left.\left({ }^{\circ} \mathrm{C}\right), \mathrm{E}-\mathrm{F}\right)$ salinity and G-H) density and $\mathrm{I}-\mathrm{J}$ ) chl- $a$ fluorescence ( $\mu$ g equiv. $\mathrm{l}^{-1}$ ) along the Scanfish track on 01 June (left panels) and 04 June 
(right panels). Sea level variations associated with the tide during the Scanfish deployment is shown in the two bottom panel.

Figure 7. Weekly variation of Pseudo-nitzschia spp. cell densities in Ria de Pontevedra (mean of 10 monitoring stations) during 2007. Error bars represent mean and standard deviation $(n=10)$.

Figure 8. Spatial and temporal distribution of A-F) Pseudo-nitzschia seriata group and G-L) P. delicatissima group cell maxima in Ría de Pontevedra during the cruise (29 May to 07 June 2007) n.d. = not detected.

Figure 9. Vertical distribution at station 2, from 29 May to 7 June, of: A-F) density (black) and chl- $a$ fluorescence (green); G-L) temperature (red) and salinity (blue).

Figure 10. Intra-tidal density $\left(\sigma_{t}\right)$ distribution during the first 24-h experiment on 29-30 May 2007 at station 2. A-L) Vertical distribution of Pseudo-nitzschia seriata group (red), $P$. delicatissima group (blue) and chl-a fluorescence (green). State of the tide, and light and dark periods are indicated on the horizontal bar above.

Figure 11. Intra-tidal density $\left(\sigma_{t}\right)$ distribution during the second 24-h experiment on 6-7 June 2007 at station 2. A-L) Vertical distribution of Pseudo-nitzschia seriata group (red), P. delicatissima group (blue) and chl- $a$ fluorescence (green). State of the tide, and light and dark periods are indicated on the horizontal bar above. 
Figure 12. Illustrations of Sea Surface Temperature (SST) from MODIS (500 m) and chl- $a$ estimates from MODIS (500 m) and MERIS (1 km) satellite data during the cruise period. AC) May 26; D-F) May 28; G-I) June 5; J-L) June 6 and M-O) June 11 2007. The corresponding tidal level is shown. White patches represent clouds.

Figure 13. A) Projection of the microphytoplankton species on the first two axes of Principal Component Analysis (PC1 and PC2). Species codes are shown in table 3. Diatoms are represented with black circles and dinoflagellates with grey triangles. Shaded area includes the most abundant species, including both groups of Pseudo-nitzschia, associated with the fluorescence. B) Relationship of PC1 and PC2 with environmental variables (temperature, salinity, sigma-t and fluorescence).

Figure 14. Vertical distributions of PC1 (left), PC2 (middle) and PC3 (right) scores extracted by the PCA of microphytoplankton species abundance ( $>20 \%$ presence), from 29 May to 4 June 2007 along Ría de Pontevedra (stations 1 to 4). Shaded areas correspond to positive scores. 


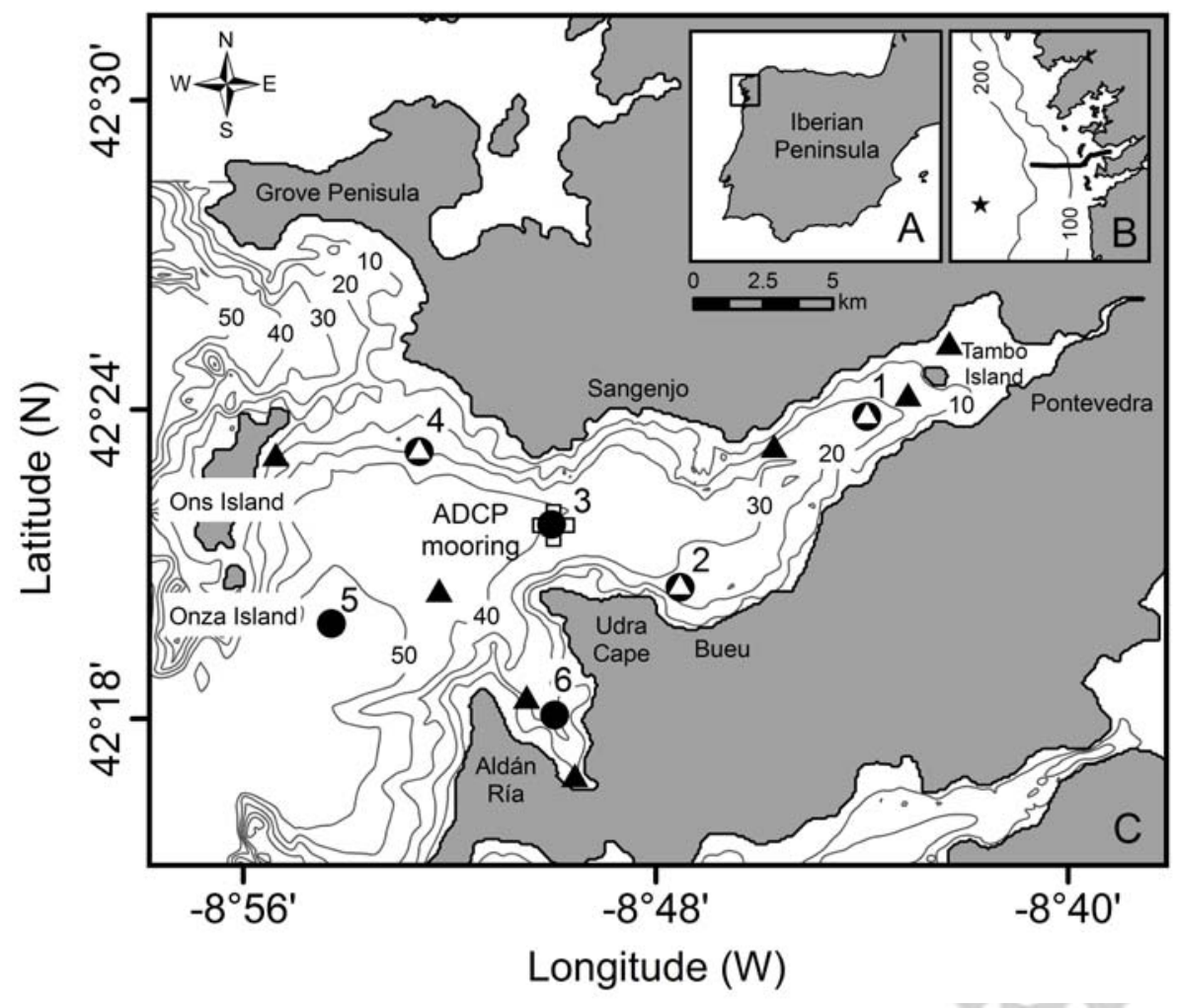




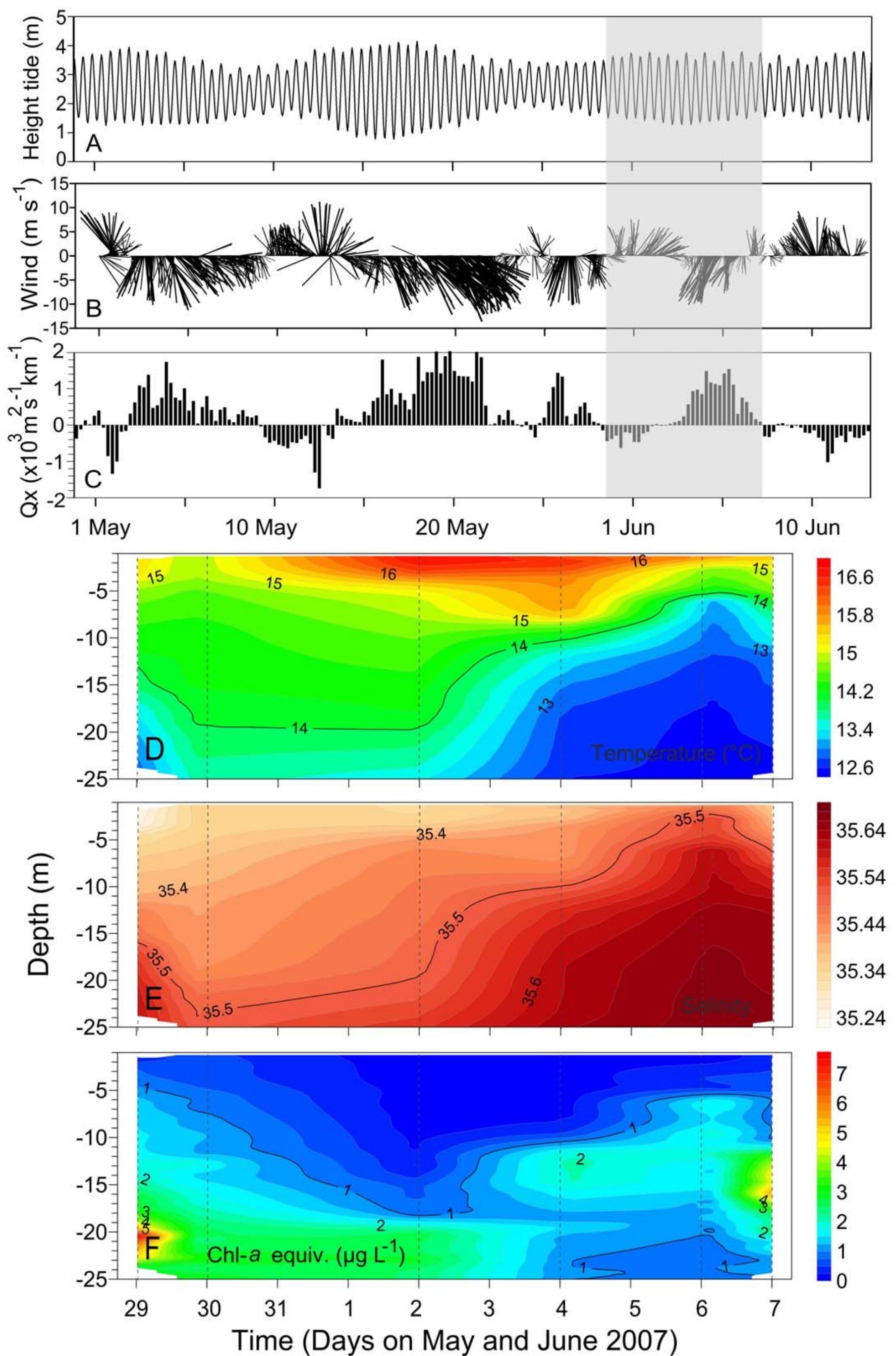




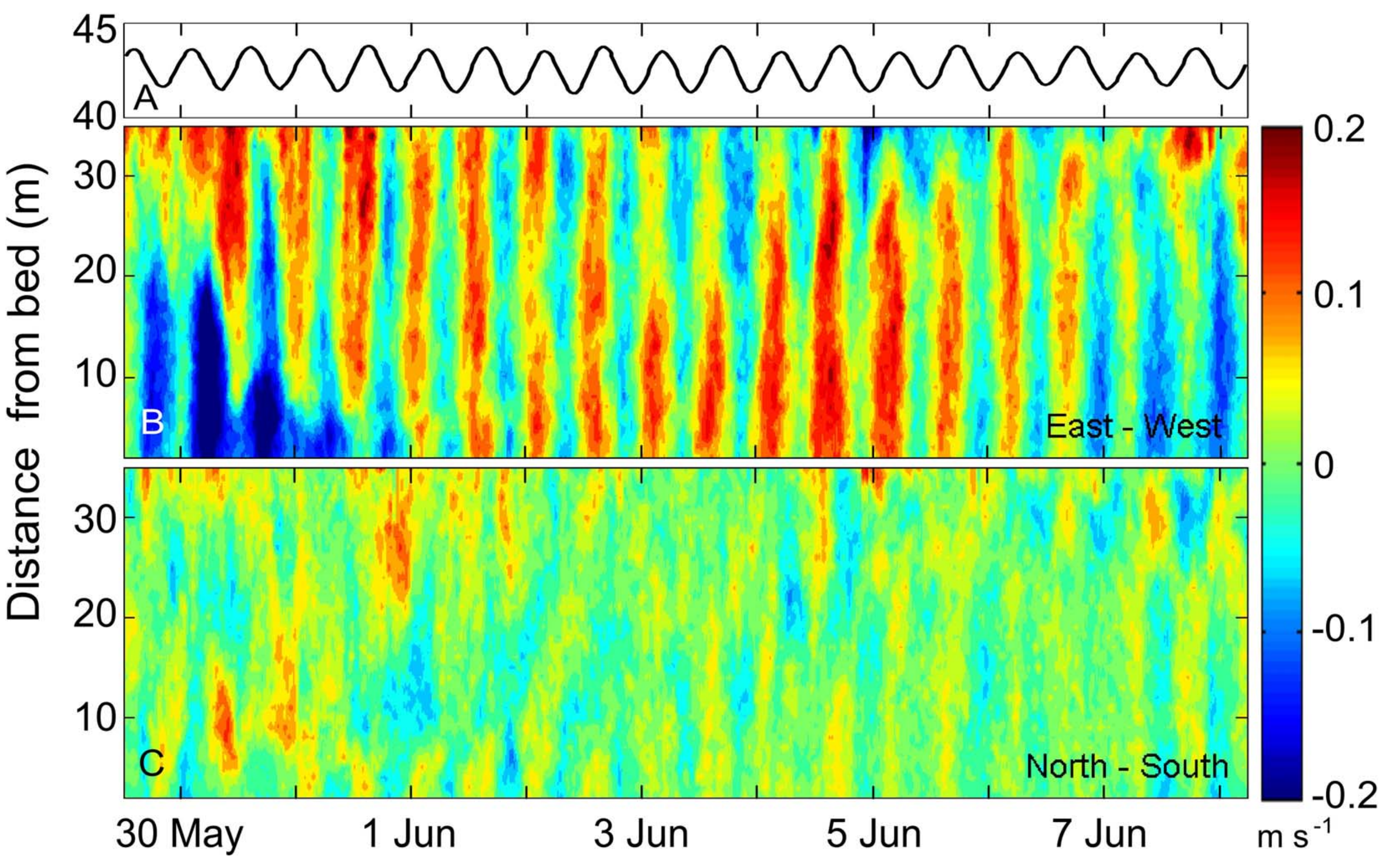



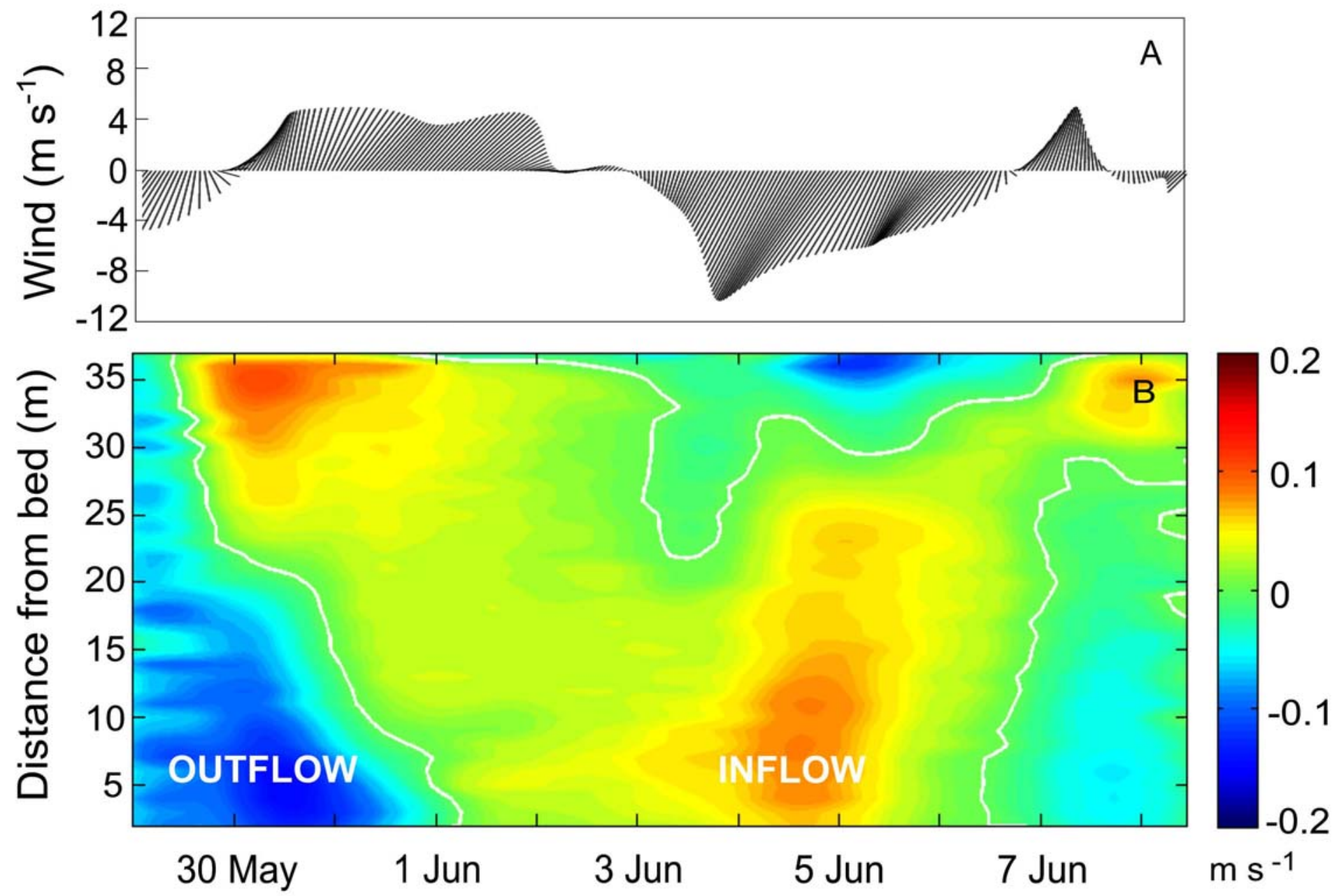


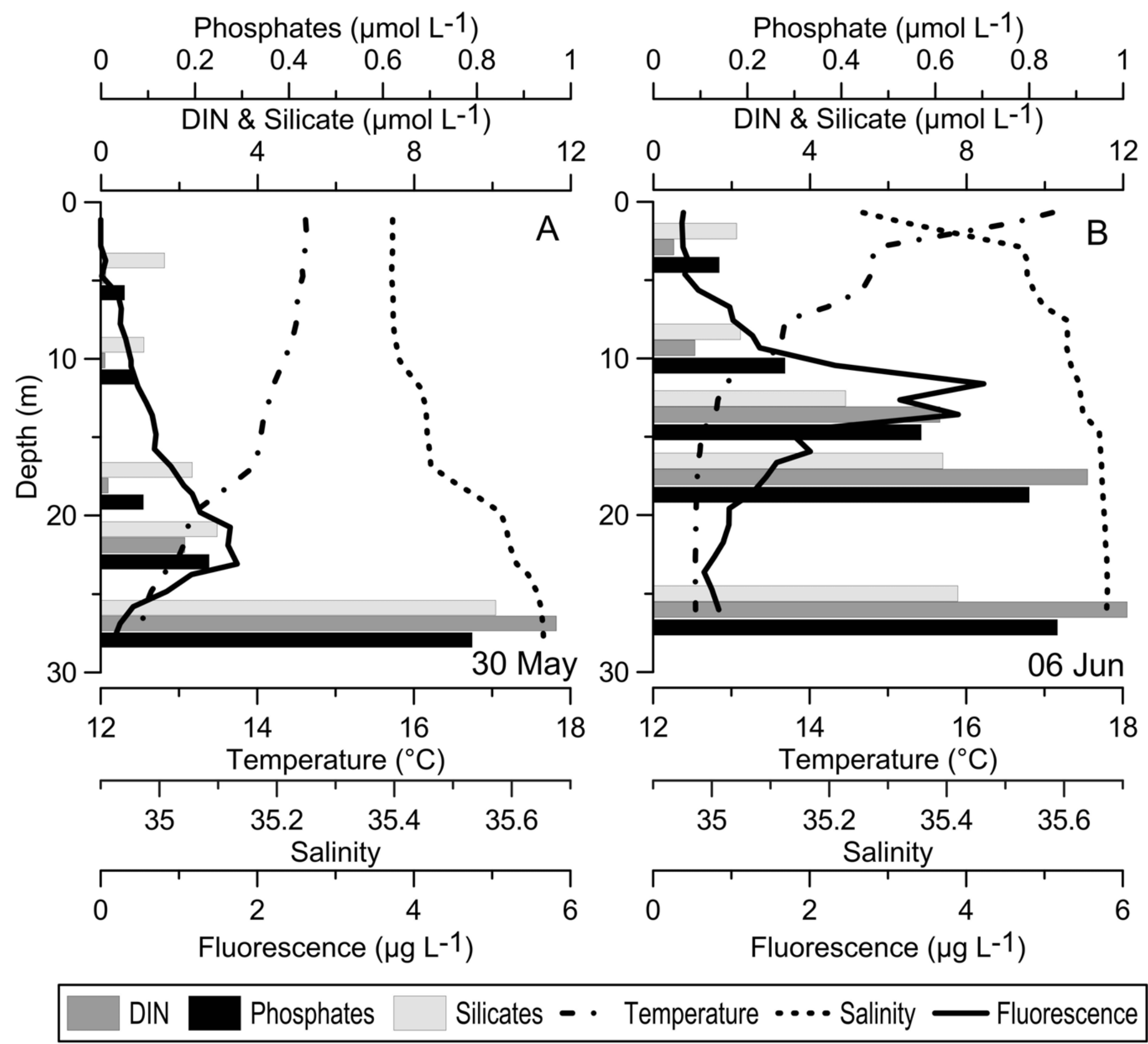




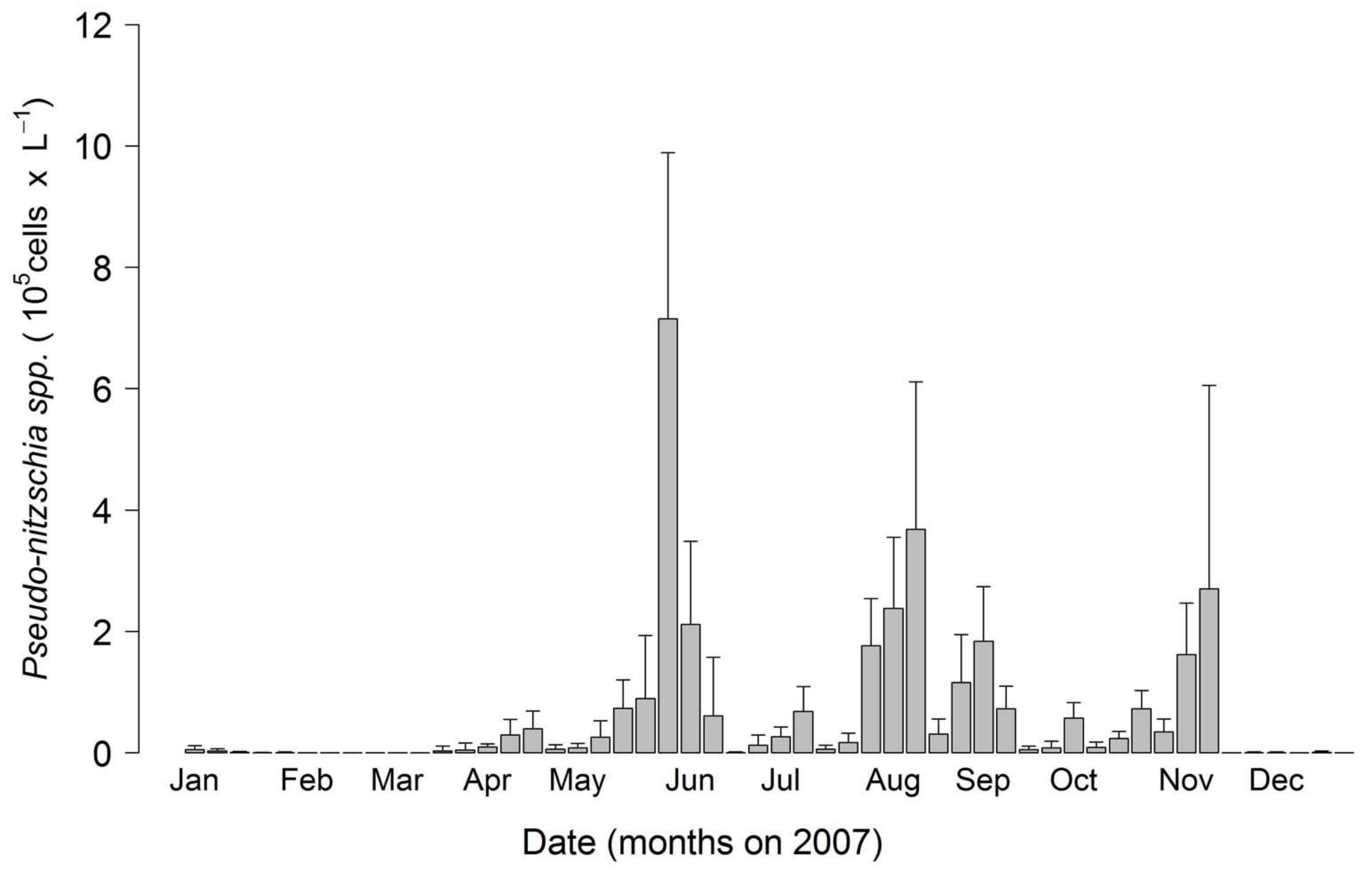




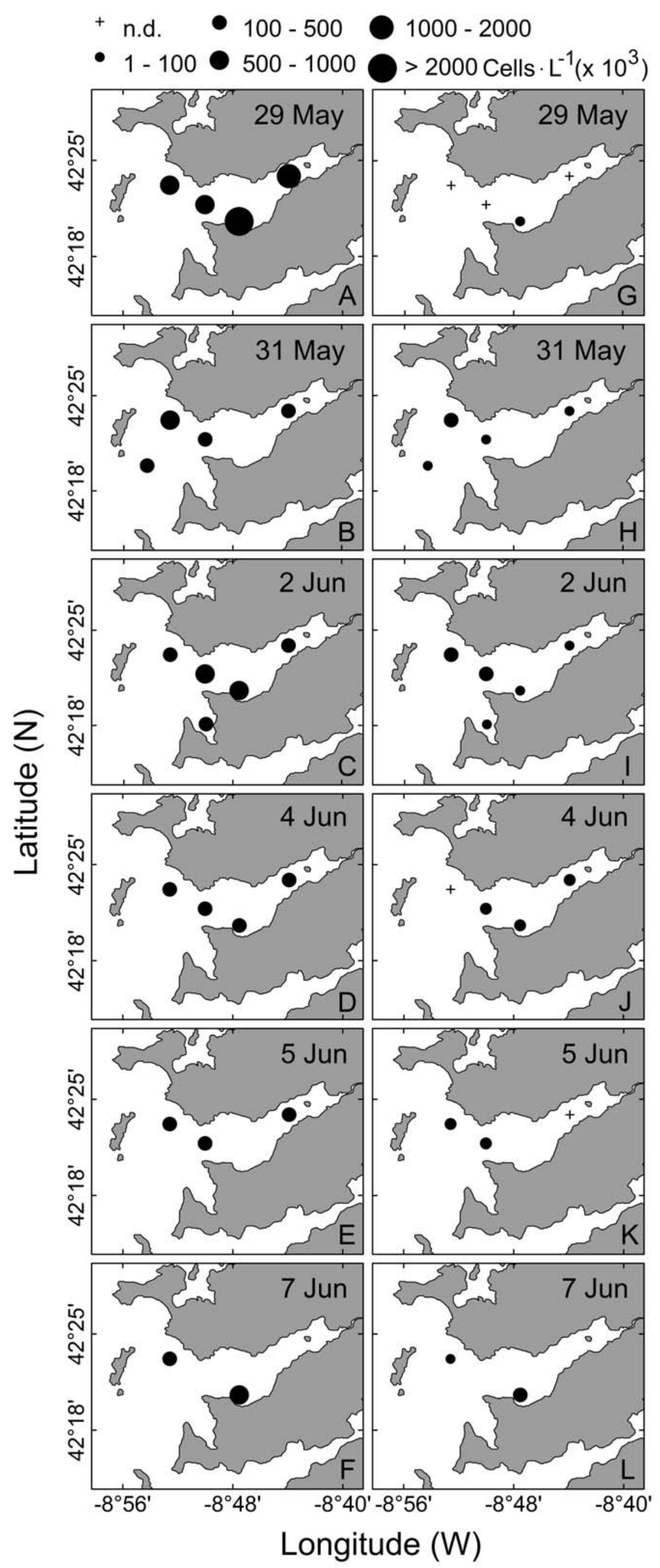




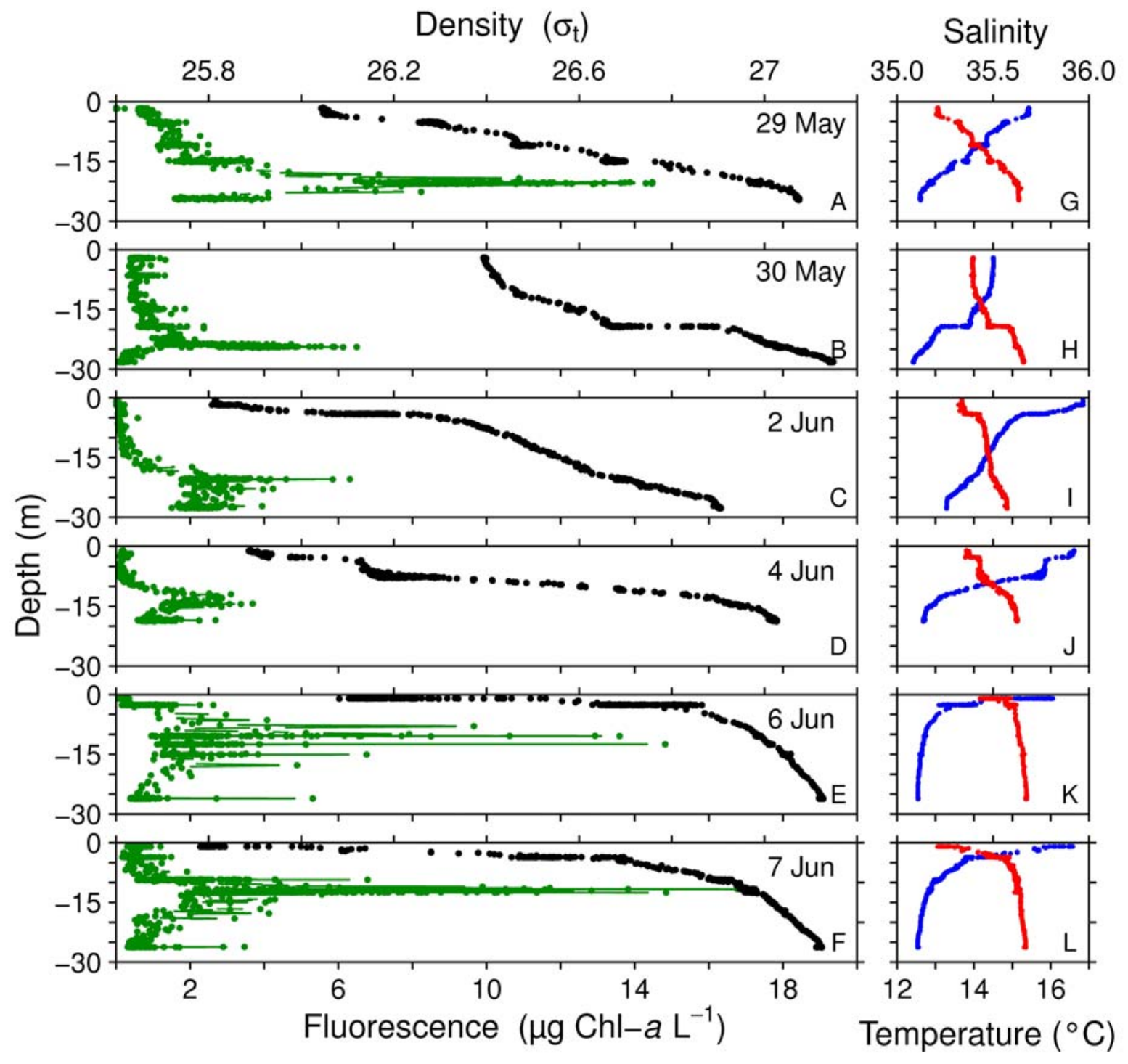




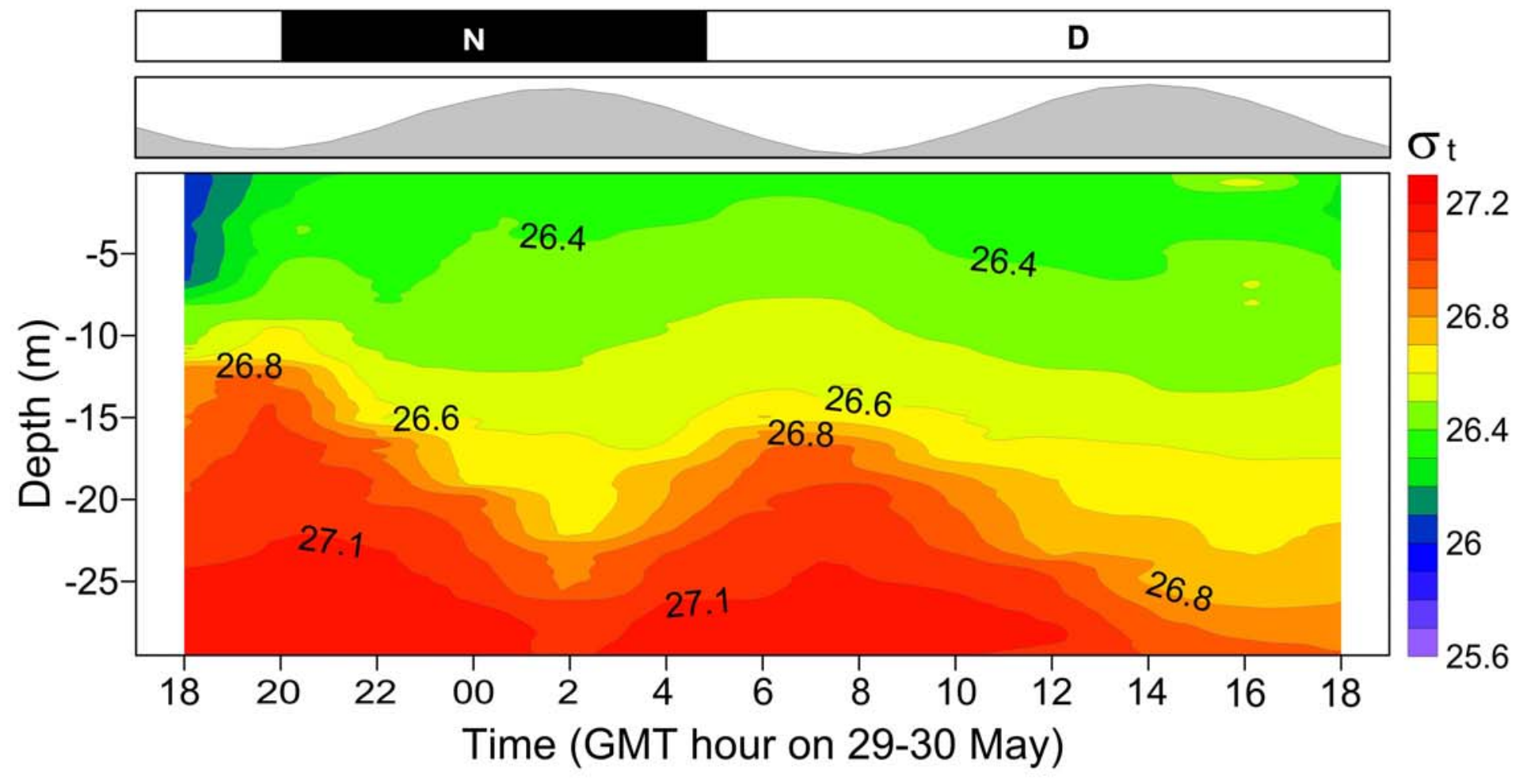

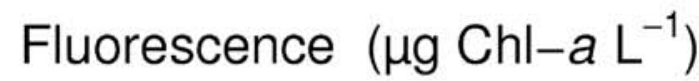

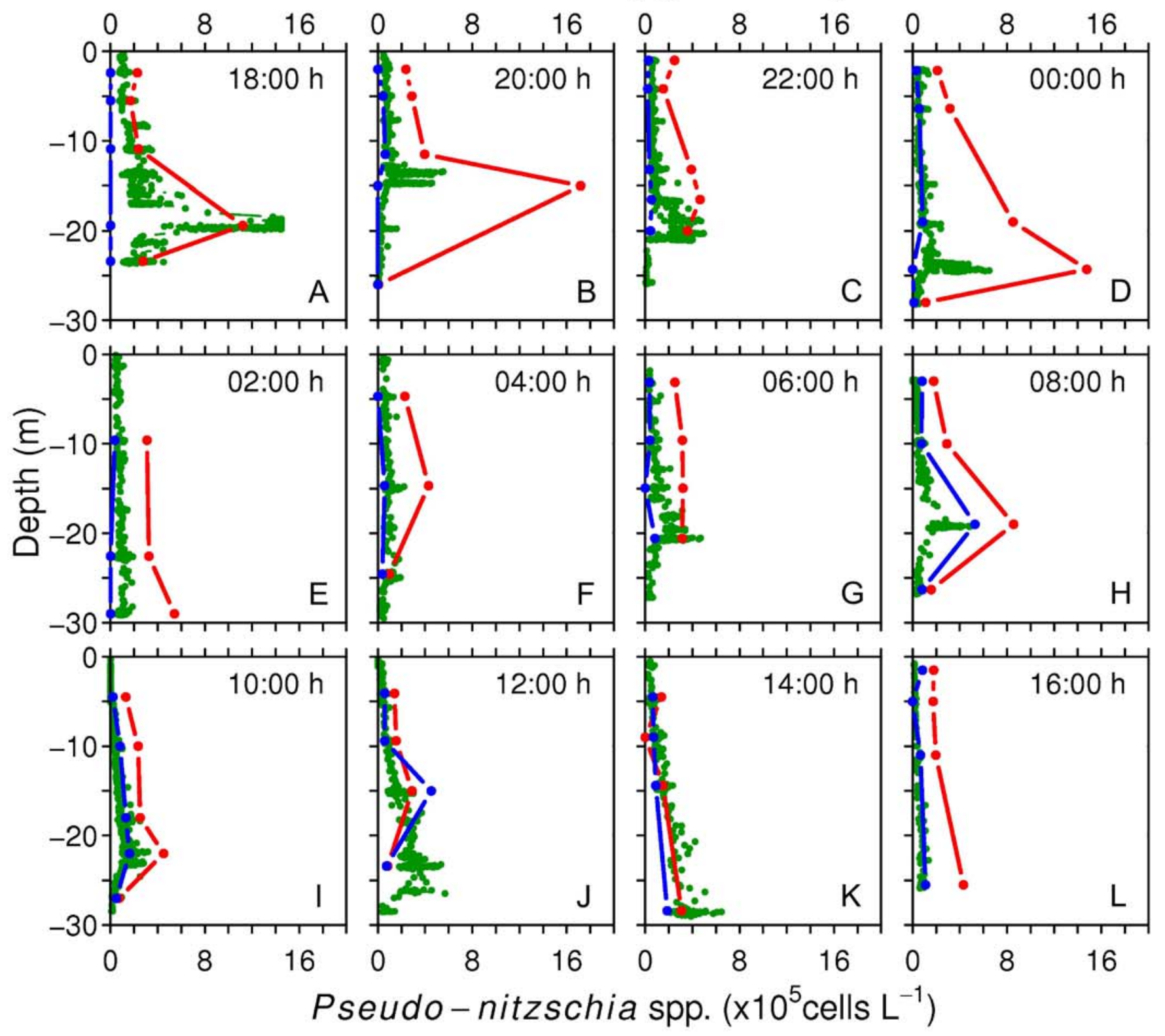




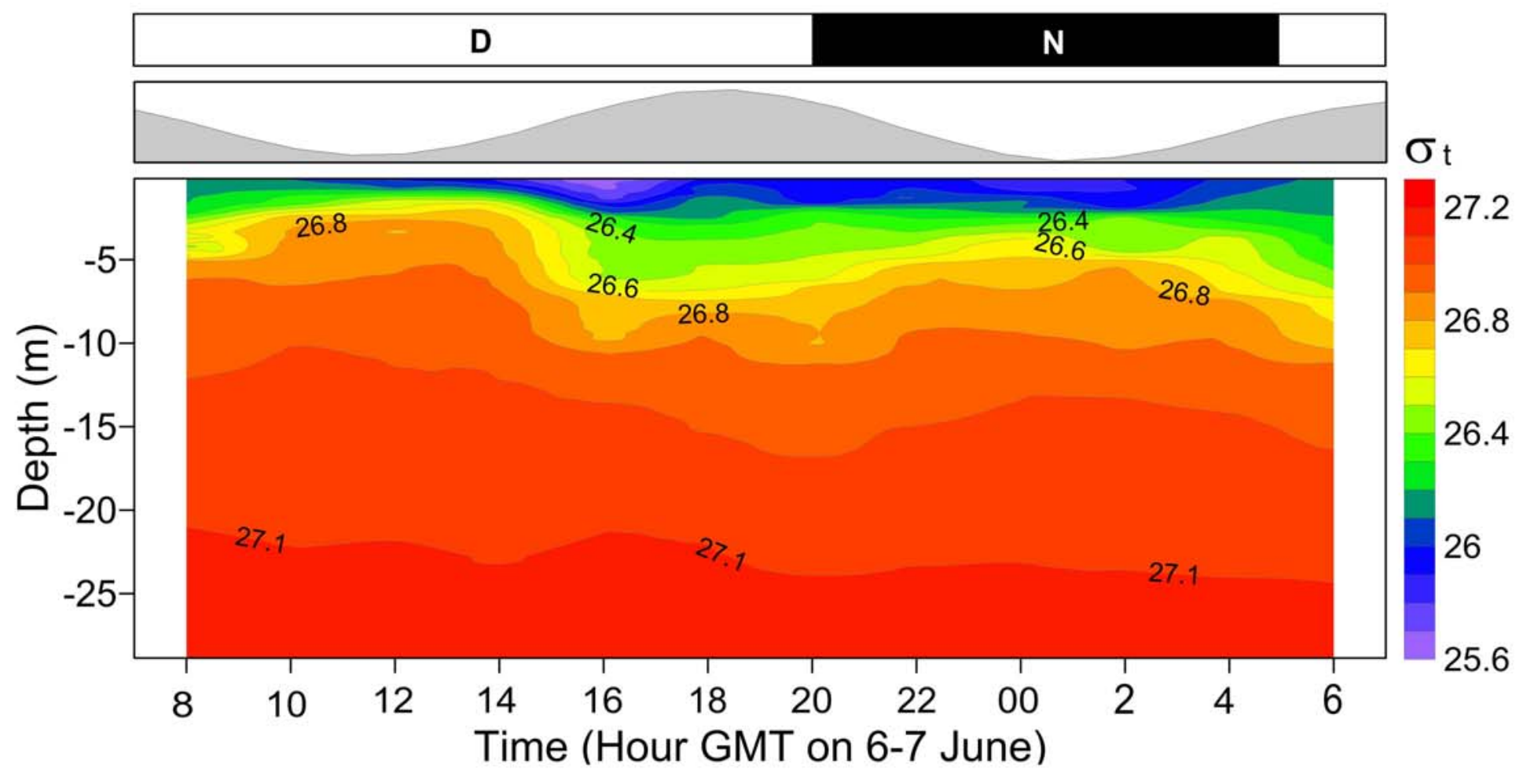

Fluorescence ( $\mu \mathrm{g} \mathrm{Chl-}-\mathrm{L} \mathrm{L}^{-1}$ )

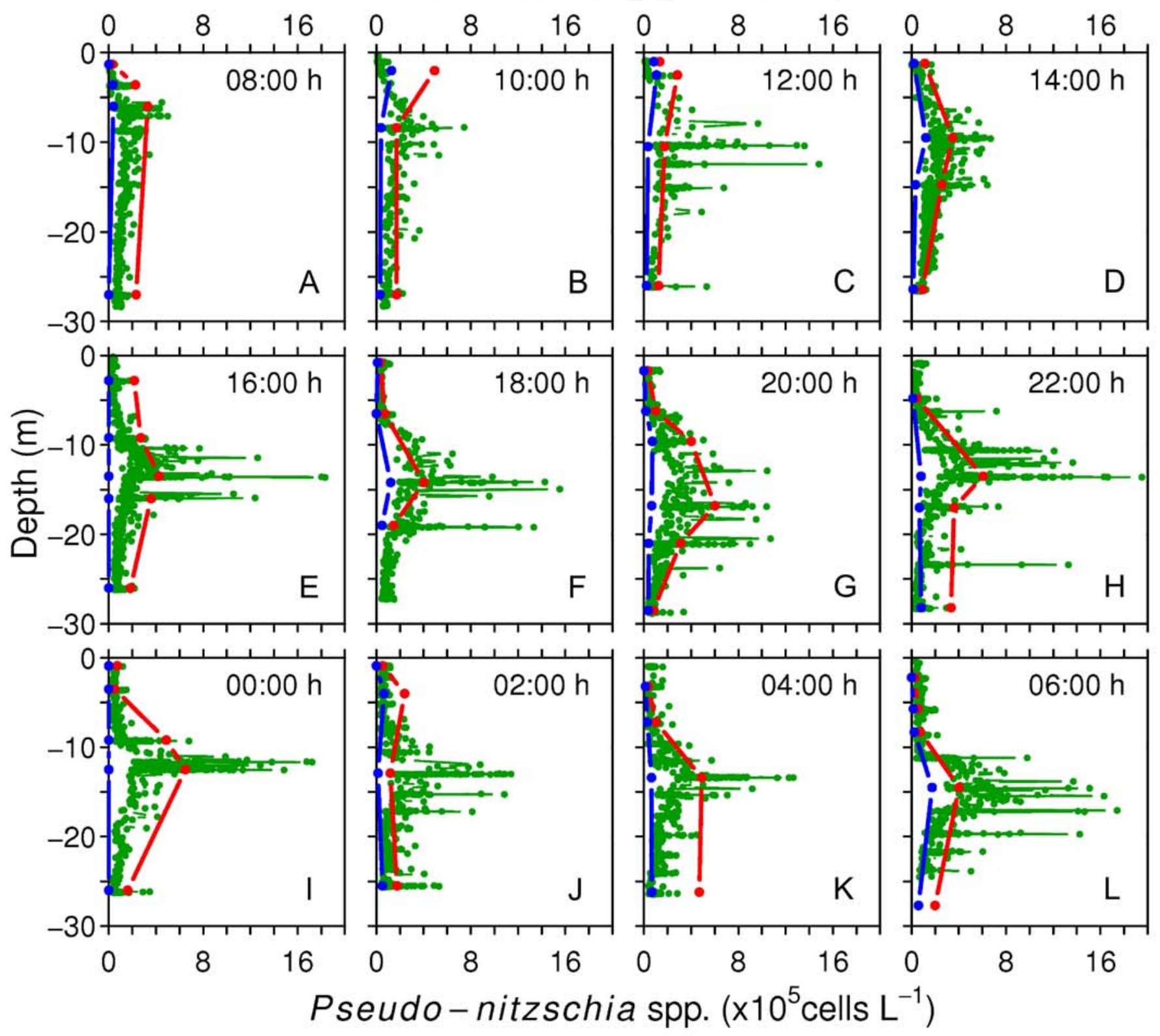



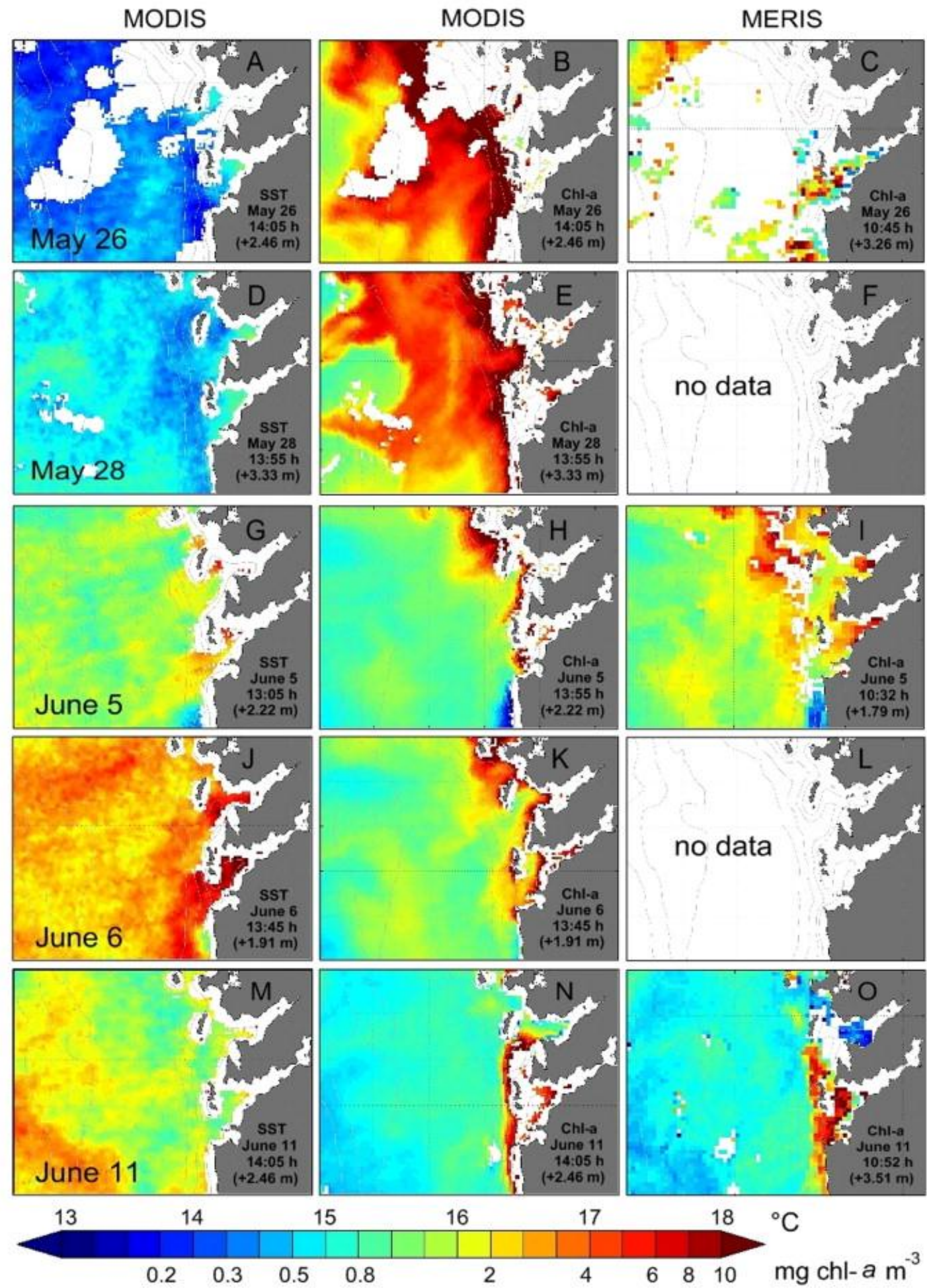


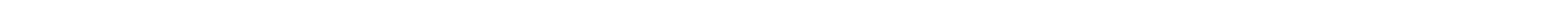

